\title{
Simulation of atmospheric mercury depletion events (AMDEs) during polar springtime using the MECCA box model
}

\author{
Z.-Q. Xie ${ }^{1, *}$, R. Sander ${ }^{2}$, U. Pöschl ${ }^{1}$, and F. Slemr ${ }^{2}$ \\ ${ }^{1}$ Biogeochemistry Department, Max Planck Institute for Chemistry, P.O. Box 3060, 55020 Mainz, Germany \\ ${ }^{2}$ Air Chemistry Department, Max Planck Institute for Chemistry, P.O. Box 3060, 55020 Mainz, Germany \\ *also at: Institute of Polar Environment, University of Science and Technology of China, Hefei, Anhui, 230026, P. R. China
}

Received: 7 May 2008 - Published in Atmos. Chem. Phys. Discuss.: 10 July 2008

Revised: 15 October 2008 - Accepted: 15 October 2008 - Published: 9 December 2008

\begin{abstract}
Atmospheric mercury depletion events (AMDEs) during polar springtime are closely correlated with brominecatalyzed tropospheric ozone depletion events (ODEs). To study gas- and aqueous-phase reaction kinetics and speciation of mercury during AMDEs, we have included mercury chemistry into the box model MECCA (Module Efficiently Calculating the Chemistry of the Atmosphere), which enables dynamic simulation of bromine activation and ODEs.

We found that the reaction of $\mathrm{Hg}$ with $\mathrm{Br}$ atoms dominates the loss of gaseous elemental mercury (GEM). To explain the experimentally observed synchronous depletion of GEM and $\mathrm{O}_{3}$, the reaction rate of $\mathrm{Hg}+\mathrm{BrO}$ has to be much lower than that of $\mathrm{Hg}+\mathrm{Br}$. The synchronicity is best reproduced with rate coefficients at the lower limit of the literature values for both reactions, i.e. $k_{\mathrm{Hg}+\mathrm{Br}} \approx 3 \times 10^{-13}$ and $k_{\mathrm{Hg}+\mathrm{BrO}} \leq 1 \times 10^{-15} \mathrm{~cm}^{3}$ molecule ${ }^{-1} \mathrm{~s}^{-1}$, respectively.

Throughout the simulated AMDEs, $\mathrm{BrHgOBr}$ was the most abundant reactive mercury species, both in the gas phase and in the aqueous phase. The aqueous-phase concentrations of $\mathrm{BrHgOBr}, \mathrm{HgBr}_{2}$, and $\mathrm{HgCl}_{2}$ were several orders of magnitude larger than that of $\mathrm{Hg}\left(\mathrm{SO}_{3}\right)_{2}^{2-}$.

Considering chlorine chemistry outside depletion events (i.e. without bromine activation), the concentration of total divalent mercury in sea-salt aerosol particles (mostly $\mathrm{HgCl}_{4}^{2-}$ ) was much higher than in dilute aqueous droplets (mostly $\mathrm{Hg}\left(\mathrm{SO}_{3}\right)_{2}^{2-}$ ), and did not exhibit a diurnal cycle (no correlation with $\mathrm{HO}_{2}$ radicals).
\end{abstract}

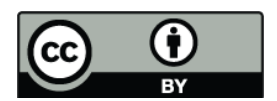

Correspondence to: Z.-Q. Xie

(zqxie@ustc.edu.cn)

\section{Introduction}

Mercury is a prominent environmental pollutant which can form toxic compounds and bioaccumulate in aquatic organisms and food chains. Due to its relatively high vapor pressure and low solubility, mercury undergoes long-range atmospheric transport to remote areas like the polar regions.

Since 1995, year-round monitoring of atmospheric $\mathrm{Hg}$ has been performed at Alert, Canada (Schroeder et al., 1998). The results indicate that gaseous elemental mercury (GEM, $\mathrm{Hg}^{0}$ ) concentrations occasionally decrease from approximately $1.7 \mathrm{ng} / \mathrm{m}^{3}$, the background level in the Northern Hemisphere (Slemr et al., 2003), to values less than $0.1 \mathrm{ng} / \mathrm{m}^{3}$ within $24 \mathrm{~h}$ or less after sunrise from late March to mid-June. Such abrupt losses of GEM are called atmospheric mercury depletion events (AMDEs), and they are closely correlated with ground level ozone depletion events (ODEs). Further investigations at Barrow, Ny-Ålesund, and Station Nord (Northeast Greenland) showed that AMDEs can occur throughout the Arctic and the sub-Arctic regions (Lindberg et al., 2002; Berg et al., 2003; Skov et al., 2004; Poissant and Pilote, 2003). Highly time-resolved measurements of mercury species and total gaseous mercury (TGM) at the Neumayer station (Ebinghaus et al., 2002) revealed that AMDEs occur also in the maritime Antarctic during austral spring. The chemical processes involved in AMDEs are, however, still not well understood, as outlined in a recent review by Steffen et al. (2008).

The depletion of GEM is thought to be due to conversion into reactive gas-phase mercury (RGM) and into particulate mercury. Lu et al. (2001) and Lu and Schroeder (2004) found an anti-correlation between measured GEM and the concentration of particulate mercury during AMDEs at Alert

Published by Copernicus Publications on behalf of the European Geosciences Union. 
Table 1. Comparison of mercury models with halogen chemistry.

\begin{tabular}{llllll}
\hline $\mathrm{Br}$ & $\mathrm{Cl}$ & aqueous phase & mass transfer & region & reference \\
\hline- & + & + & dynamic $\left(k_{\mathrm{mt}}\right)$ & Northern Hemisphere & Christensen et al. (2004) \\
- & + & + & equilibrium & Northern Hemisphere & Travnikov (2005) \\
- & + & + & dynamic $\left(k_{\mathrm{mt}}\right)$ & global & Dastoor and Larocque (2004) \\
+ & + & - & - & polar & Calvert and Lindberg $(2003)$ \\
+ & + & - & - & Northern Hemisphere & Skov et al. (2004) \\
- & + & dilute droplets & equilibrium & unspecified & Pan and Carmichael (2005) \\
- & + & dilute droplets & equilibrium & unspecified & Seigneur et al. (1994) \\
- & + & dilute droplets & dynamic $\left(k_{\mathrm{mt}}\right)$ & unspecified & Pleijel and Munthe (1995) \\
+ & + & aerosol & dynamic $\left(k_{\mathrm{mt}}\right)$ & remote marine boundary layer & Hedgecock and Pirrone $(2001)$ \\
+ & + & aerosol & dynamic $\left(k_{\mathrm{mt}}\right)$ & Mediterranean & Hedgecock et al. (2003) \\
+ & + & aerosol & dynamic $\left(k_{\mathrm{mt}}\right)$ & marine boundary layer & Hedgecock and Pirrone $(2004)$ \\
+ & + & aerosol & dynamic $\left(k_{\mathrm{mt}}\right)$ & Mediterranean & Hedgecock et al. (2005) \\
+ & + & aerosol & dynamic $\left(k_{\mathrm{mt}}\right)$ & polar & Hedgecock et al. (2008) \\
+ & + & aerosol & dynamic $\left(k_{\mathrm{mt}}\right)$ & urban & Shon et al. (2005) \\
+ & + & aerosol & dynamic $\left(k_{\mathrm{mt}}\right)$ & polar & this work \\
\hline
\end{tabular}

in 1998. The chemical reactions causing the AMDEs (Lindberg et al., 2001, 2002; Ariya et al., 2002; Calvert and Lindberg, 2004b; Goodsite et al., 2004) are probably similar to those driving the ozone depletion events (Bottenheim et al., 1986; Barrie et al., 1988; Simpson et al., 2007), and the oxidation of GEM by reactive halogen species like $\mathrm{Br}$ atoms and $\mathrm{BrO}$ radicals is considered to be a key process of mercury depletion (Ariya et al., 2004; Calvert and Lindberg, 2004a; Goodsite et al., 2004; Skov et al., 2004).

Reactive bromine species can be generated from sea salt aerosols and in the course of sea ice formation, when concentrated salt solutions (brine) are separated from ice. When an open lead of sea water begins to freeze over, it often forms frost flowers. These are dendritic vapor-deposited ice crystals that wick brine from the freezing ice (Perovich and Richter-Menge, 1994; Rankin et al., 2002; Canosa-Mas et al., 1996) and can serve as sites of halogen activation and sources of sea salt aerosols (Simpson et al., 2007). Recently, Sander et al. (2006) used the MECCA (Module Efficiently Calculating the Chemistry of the Atmosphere) box model to study the role of carbonate precipitation in freezing sea water for the generation of reactive bromine. To link the process of halogen activation in sea salt aerosols over nascent sea ice with AMDEs and investigate its potential impact, we have added mercury chemistry to MECCA.

For comparison, other model studies of atmospheric mercury chemistry are listed in Table 1 and shortly summarized here. Ryaboshapko et al. (2002) compared several mercury chemistry models. These models have been commonly used to study the long-range transport of mercury. They contain chemical reactions of $\mathrm{Hg}$ species related to $\mathrm{SO}_{2}$ and chlorine but they do not consider bromine chemistry. Pan and Carmichael (2005) and Seigneur et al. (1994) studied mercury atmospheric mechanisms with a box model, assuming gas/aqueous-phase partitioning according to Henry's law, while Pleijel and Munthe (1995) updated the partitioning considering dynamic mass transfer. Outside of the polar regions, only a few studies include bromine chemistry. Holmes et al. (2006) simulated the global mean atmospheric lifetime of elemental mercury against oxidation by atomic bromine in the troposphere. Hedgecocks' research group added bromine chemistry to AMCOTS (Atmospheric Mercury Chemistry Over The Sea) and studied the Mediterranean or remote marine boundary layer (Hedgecock and Pirrone, 2001; Hedgecock et al., 2003; Hedgecock and Pirrone, 2004; Hedgecock et al., 2005). Shon et al. (2005) modeled atmospheric mercury and bromine chemistry in urban air in a coastal city. Within the Arctic region, two hemispheric models (DEHM by Christensen et al., 2004, and MSCE-Hg by Travnikov, 2005) and a global model (GRAHM by Dastoor and Larocque, 2004) have been used to model AMDEs. The mercury chemistry in these studies is mostly based on the scheme from Peterson et al. (1998), which does not include bromine chemistry. Skov et al. (2004) developed a parameterization for DEHM to study AMDEs. However, they could not describe the fast variations of GEM as observed during spring. Calvert and Lindberg (2003) studied the influence of bromine chemistry on AMDEs. Their simulated rate of $\mathrm{Hg}$ depletion is dependent on the $\mathrm{Hg}+\mathrm{BrO}$ reaction. Since the concentration of the $\mathrm{BrO}$ radical will be many times that of the $\mathrm{Br}$ atoms in the $\mathrm{O}_{3}$-rich troposphere, $\mathrm{BrO}$ may thus be an important oxidant for GEM. However, their model used prescribed fluxes of $\mathrm{Br}_{2}$ and $\mathrm{BrCl}$, and the mechanism did not consider aqueous-phase reactions. More recently, Hedgecock et al. (2008) published a simulation of AMDEs with AMCOTS and a chemistry scheme based on MOCCA (the predecessor of MECCA). They used measured rate constants for the reaction of $\mathrm{Hg}$ with $\mathrm{Br}$ but did not consider aqueousphase species. The work presented here is to constrain the rate for $\mathrm{Hg}$ with bromine and study the oxidized species both 


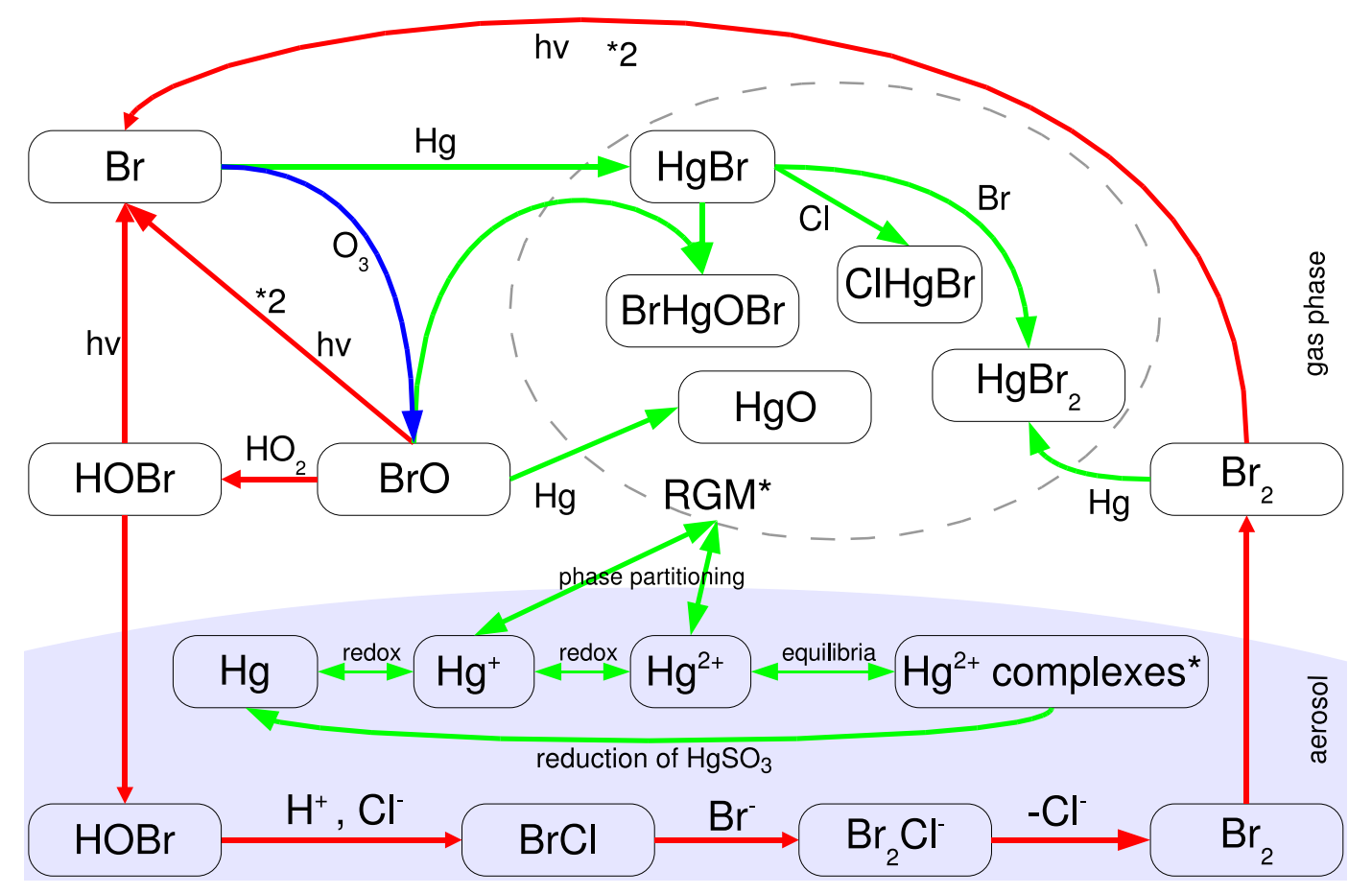

Fig. 1. Simplified halogen and mercury chemistry. Bromine chemistry is shown with red arrows, Hg chemistry in green, and ozone destruction in blue. "RGM*" refers to all gas-phase species in our model that contain mercury, except for elemental $\mathrm{Hg}^{*} \mathrm{Hg}^{2+}$ complexes* refers to $\mathrm{HgSO}_{3}, \mathrm{Hg}\left(\mathrm{SO}_{3}\right)_{2}^{2-}, \mathrm{Hg}(\mathrm{OH})_{2}, \mathrm{HgOHCl}, \mathrm{HgCl}^{+}, \mathrm{HgCl}_{2}, \mathrm{HgCl}_{3}^{-}, \mathrm{HgCl}_{4}^{2-}, \mathrm{HgBr}^{+}, \mathrm{HgBr}_{2}, \mathrm{HgBr}_{3}^{-}$and $\mathrm{HgBr}_{4}^{2-}$.

in the gas and the aqueous phase including bromine chemistry with a fully coupled gas/aqueous chemistry mechanism.

\section{Model description}

We have used the atmospheric chemistry box model MECCA by Sander et al. (2005). It describes the release of halogens from sea salt aerosols under conditions of the polar boundary layer at $82^{\circ} \mathrm{N}$ with a fully $\mathrm{pH}$-dependent aqueous-phase chemistry mechanism. Here, we added mercury chemistry to the polar MECCA model. In the current model version, there are a total of 686 equations (178 gas-phase equations; 250 aqueous-phase equations; 138 Henry's law equations; 70 equilibria; 48 photolyses). The set of ordinary differential equations is integrated with the KPP software package (Sandu and Sander, 2006), using the Rosenbrock method RODAS3. The release process of reactive halogens and the reactions with mercury and ozone both in the aerosol and the gas phase are shown in Fig. 1. Dry deposition is switched off in the model because under the conditions of our model calculations, there is enough aerosol surface available so that uptake of RGM to aerosols dominates over dry deposition. MECCA only simulates locally occurring chemistry; advection of an air mass already depleted in GEM and RGM cannot be modeled.

\subsection{Gas-phase oxidation reactions}

Potential reactions of $\mathrm{Hg}$ in the atmosphere have recently been summarized by Steffen et al. (2008). The primary reactions include the oxidation by $\mathrm{O}_{3}$ (Pal and Ariya, 2004b), the $\mathrm{OH}$ radical (Sommar et al., 2001; Pal and Ariya, 2004a), $\mathrm{H}_{2} \mathrm{O}_{2}$ (Tokos et al., 1998) and reactive halogen species (Ariya et al., 2002; Calvert and Lindberg, 2003, 2004a; Raofie and Ariya, 2003; Donohoue et al., 2005, 2006). Table 2 shows the reactions and their rate constants. There is a wide range of rate constants for GEM oxidation by $\mathrm{O}_{3}$ and $\mathrm{OH}$. Here, the temperature-dependent kinetic data reported by Pal and Ariya (2004a) and Pal and Ariya (2004b) are used. It should be noted that Seigneur et al. (2006) and Selin et al. (2007) found that this rate coefficient for $\mathrm{Hg}+\mathrm{O}_{3}$ depletes GEM too fast in a global one-year simulation. However, on the time scale of AMDEs (several days), the reaction $\mathrm{Hg}+\mathrm{O}_{3}$ is negligible, even when using the fast rate coefficient.

The reactions of $\mathrm{Hg}$ with $\mathrm{O}_{3}$ and $\mathrm{OH}$ are potentially important pathways for the loss of $\mathrm{Hg}$ in the continental troposphere, while in the marine boundary layer and the upper troposphere halogens are presumed to be dominant oxidants (Lin et al., 2006). The rate coefficients for the reactions of molecular halogens $\left(\mathrm{Br}_{2}\right.$ and $\left.\mathrm{Cl}_{2}\right)$ and $\mathrm{Br}$ and $\mathrm{Cl}$ atoms and $\mathrm{BrO}$ with gas-phase $\mathrm{Hg}$ atoms have been investigated (e.g. Ariya et al., 2002; Raofie and Ariya, 2003). Although the 
Table 2. Gas-phase reactions.

\begin{tabular}{lll}
\hline & $k\left[\mathrm{~cm}^{3}\right.$ molecule $\left.^{-1} \mathrm{~s}^{-1}\right]$ & reference \\
\hline $\mathrm{Hg}+\mathrm{O}_{3} \rightarrow \mathrm{HgO}+\mathrm{O}_{2}$ & $8.43 \mathrm{E}-17 \times \exp (-1407 \mathrm{~K} / T)$ & Pal and Ariya (2004b), see also Sect. 2.1 \\
$\mathrm{Hg}+\mathrm{OH} \rightarrow \mathrm{HgO}+\mathrm{H}$ & $3.55 \mathrm{E}-14 \times \exp (294 \mathrm{~K} / T)$ & Pal and Ariya (2004a) \\
$\mathrm{Hg}+\mathrm{H}_{2} \mathrm{O}_{2} \rightarrow \mathrm{HgO}+\mathrm{H}_{2} \mathrm{O}$ & $8.5 \mathrm{E}-19$ & Tokos et al. (1998) \\
$\mathrm{Hg}+\mathrm{Cl} \rightarrow \mathrm{HgCl}$ & $1.0 \mathrm{E}-11$ & Ariya et al. (2002) \\
$\mathrm{Hg}+\mathrm{Cl}{ }_{2} \rightarrow \mathrm{HgCl} 2$ & $2.6 \mathrm{E}-18$ & Ariya et al. (2002) \\
$\mathrm{Hg}+\mathrm{Br} \rightarrow \mathrm{HgBr}$ & $3.0 \mathrm{E}-13$ & Donohoue et al. (2006) \\
$\mathrm{HgBr}+\mathrm{Br} \rightarrow \mathrm{HgBr} 2$ & $3.0 \mathrm{E}-12$ & Calvert and Lindberg (2003) \\
$\mathrm{Hg}+\mathrm{Br} \rightarrow \rightarrow \mathrm{HgBr} 2$ & $9.0 \mathrm{E}-17$ & Ariya et al. (2002) \\
$\mathrm{Hg}+\mathrm{BrO} \rightarrow \mathrm{HgO}+\mathrm{Br}$ & $1.0 \mathrm{E}-15$ & Raofie and Ariya (2003) \\
$\mathrm{HgBr}+\mathrm{BrO} \rightarrow \mathrm{BrHgOBr}$ & $3.0 \mathrm{E}-12$ & see note \\
$\mathrm{HgCl}+\mathrm{BrO} \rightarrow \mathrm{ClHgOBr}$ & $3.0 \mathrm{E}-12$ & see note \\
$\mathrm{HgBr}+\mathrm{Cl} \rightarrow \mathrm{ClHgBr}$ & $3.0 \mathrm{E}-12$ & see note $^{\mathrm{a}}$ \\
$\mathrm{HgCl}+\mathrm{Br} \rightarrow \mathrm{ClHgBr}$ & $3.0 \mathrm{E}-12$ & see note $^{\mathrm{a}}$ \\
\hline
\end{tabular}

${ }^{\text {a }}$ Since the kinetics of these reactions have neither been studied theoretically nor experimentally, we have used the value $k(\mathrm{HgBr}+\mathrm{Br}) \mathrm{here}$, as assumed by Calvert and Lindberg (2003).

Table 3. Aqueous-phase reactions.

\begin{tabular}{|c|c|c|c|}
\hline & $k$ & & reference \\
\hline $\mathrm{Hg}+\mathrm{O}_{3} \rightarrow \mathrm{HgO}+\mathrm{O}_{2}$ & 4.7E7 & $\mathrm{M}^{-1} \mathrm{~s}^{-1}$ & Munthe (1992) \\
\hline $\mathrm{HgO}+\mathrm{H}^{+} \rightarrow \mathrm{Hg}^{2+}+\mathrm{OH}^{-}$ & $1.0 \mathrm{E} 10$ & $\mathrm{M}^{-1} \mathrm{~s}^{-1}$ & Pleijel and Munthe (1995) \\
\hline $\mathrm{Hg}+\mathrm{OH} \rightarrow \mathrm{Hg}^{+}+\mathrm{OH}^{-}$ & $2.0 \mathrm{E} 9$ & $\mathrm{M}^{-1} \mathrm{~s}^{-1}$ & Lin and Pehkonen (1997) \\
\hline $\mathrm{Hg}^{+}+\mathrm{OH} \rightarrow \mathrm{Hg}^{2+}+\mathrm{OH}^{-}$ & $1.0 \mathrm{E} 10$ & $\mathrm{M}^{-1} \mathrm{~s}^{-1}$ & Lin and Pehkonen (1997) \\
\hline $\mathrm{Hg}^{2+}+\mathrm{HO}_{2} \rightarrow \mathrm{Hg}^{+}+\mathrm{O}_{2}+\mathrm{H}^{+}$ & $1.7 \mathrm{E} 4$ & $\mathrm{M}^{-1} \mathrm{~s}^{-1}$ & Pehkonen and Lin (1998) \\
\hline $\mathrm{Hg}^{+}+\mathrm{HO}_{2} \rightarrow \mathrm{Hg}+\mathrm{O}_{2}+\mathrm{H}^{+}$ & $1.0 \mathrm{E} 10$ & $\mathrm{M}^{-1} \mathrm{~s}^{-1}$ & 1 \\
\hline $\mathrm{Hg}+\mathrm{HOCl} \rightarrow \mathrm{Hg}^{2+}+\mathrm{Cl}^{-}+\mathrm{OH}^{-}$ & 2.09E6 & $\mathrm{M}^{-1} \mathrm{~s}^{-1}$ & Lin and Pehkonen (1998) \\
\hline $\mathrm{Hg}+\mathrm{ClO}^{-} \stackrel{\mathrm{H}^{+}}{\rightarrow} \mathrm{Hg}^{2+}+\mathrm{Cl}^{-}+\mathrm{OH}^{-}$ & $1.99 \mathrm{E} 6$ & $\mathrm{M}^{-1} \mathrm{~s}^{-1}$ & Lin and Pehkonen (1998) \\
\hline $\mathrm{Hg}+\mathrm{HOBr} \rightarrow \mathrm{Hg}^{2+}+\mathrm{Br}^{-}+\mathrm{OH}^{-}$ & 0.279 & $\mathrm{M}^{-1} \mathrm{~s}^{-1}$ & Wang and Pehkonen (2004) \\
\hline $\mathrm{Hg}+\mathrm{BrO}^{-} \stackrel{\mathrm{H}^{+}}{\rightarrow} \mathrm{Hg}^{2+}+\mathrm{Br}^{-}+\mathrm{OH}^{-}$ & 0.273 & $\mathrm{M}^{-1} \mathrm{~s}^{-1}$ & Wang and Pehkonen (2004) \\
\hline $\mathrm{Hg}+\mathrm{Br}_{2} \rightarrow \mathrm{Hg}^{2+}+2 \mathrm{Br}^{-}$ & 0.196 & $\mathrm{M}^{-1} \mathrm{~s}^{-1}$ & Wang and Pehkonen (2004) \\
\hline $\mathrm{HgSO}_{3} \stackrel{\mathrm{H}_{2} \mathrm{O}}{\rightarrow} \mathrm{Hg}+\mathrm{HSO}_{4}^{-}+\mathrm{H}^{+}$ & 0.0106 & $\mathrm{~s}^{-1}$ & van Loon et al. (2000) \\
\hline $\mathrm{Hg}(\mathrm{OH})_{2} \stackrel{h v}{\rightarrow} \mathrm{Hg}+2 \mathrm{OH}$ & 2 & & Xiao et al. (1994) \\
\hline
\end{tabular}

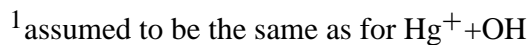

2 follows a diurnal cycle with a peak of about $3 \mathrm{E}-7 \mathrm{~s}^{-1}$

role of halogens in GEM depletion in the atmosphere is still uncertain and argued, it is known that reactions of $\mathrm{Hg}$ with $\mathrm{Br}_{2}, \mathrm{Cl}_{2}, \mathrm{Br}, \mathrm{Cl}$, and $\mathrm{BrO}$ are involved. There are only a few reports on the association reactions of $\mathrm{HgBr}$ with $\mathrm{Br}, \mathrm{Cl}$, $\mathrm{BrO}$, and $\mathrm{HgCl}$ with $\mathrm{Br}$ and $\mathrm{BrO}$ radicals. The rate coefficients have not yet been determined experimentally. A value consistent with those measured for similar association reactions is assumed.

\subsection{Aqueous-phase redox chemistry}

In contrast to the gas phase, aqueous-phase reactions of mercury include both oxidation and reduction (Table 3). Potential aqueous oxidants are $\mathrm{O}_{3}$ (Munthe, 1992), the $\mathrm{OH}$ radical (Lin and Pehkonen, 1997), $\mathrm{HOCl} / \mathrm{ClO}^{-}$(Lin and Pehkonen, 1998), and $\mathrm{Br}_{2} / \mathrm{HOBr} / \mathrm{BrO}^{-}$(Wang and Pehkonen, 2004). In the aqueous phase, the chemical lifetime of $\mathrm{Hg}$ against oxidation is much less than in the gas phase. For the reduction of aqueous $\mathrm{Hg}^{2+}$, dissolved S(IV) (e.g. van Loon et al., 2000), $\mathrm{HO}_{2}$ (Pehkonen and Lin, 1998) and the photolysis of $\mathrm{Hg}(\mathrm{OH})_{2}$ may be responsible. As the photolysis of $\mathrm{Hg}(\mathrm{OH})_{2}$ 
Table 4. Aqueous-phase equilibria.

\begin{tabular}{lll}
\hline equilibrium & $K\left[\mathrm{M}^{-1}\right]$ & reference \\
\hline $\mathrm{Hg}^{2+}+\mathrm{OH}^{-} \rightleftharpoons \mathrm{HgOH}^{+}$ & $4.0 \mathrm{E} 10$ & see note $^{\mathrm{a}}$ \\
$\mathrm{HgOH}^{+}+\mathrm{OH}^{-} \rightleftharpoons \mathrm{Hg}(\mathrm{OH})_{2}$ & $1.58 \mathrm{E} 11$ & see note \\
$\mathrm{Hg}^{2+}+\mathrm{SO}_{3}^{2-} \rightleftharpoons \mathrm{HgSO}_{3}$ & $2 . \mathrm{E} 13$ & van Loon et al. (2001) \\
$\left.\mathrm{HgSO}_{3}+\mathrm{SO}_{3}^{2-} \rightleftharpoons \mathrm{Hg}_{(} \mathrm{SO}_{3}\right)_{2}^{2-}$ & $1 . \mathrm{E} 10$ & van Loon et al. (2001) \\
$\mathrm{Hg}^{2+}+\mathrm{Cl}^{-} \rightleftharpoons \mathrm{HgCl}^{+}$ & $5.8 \mathrm{E} 6$ & Hepler and Olofsson (1975) \\
$\mathrm{HgCl}^{+}+\mathrm{Cl}^{-} \rightleftharpoons \mathrm{HgCl}_{2}$ & $2.5 \mathrm{E} 6$ & Hepler and Olofsson (1975) \\
$\mathrm{HgCl}_{2}+\mathrm{Cl}^{-} \rightleftharpoons \mathrm{HgCl}_{3}^{-}$ & 6.7 & Hepler and Olofsson (1975) \\
$\mathrm{HgCl}_{3}^{-}+\mathrm{Cl}^{-} \rightleftharpoons \mathrm{HgCl}_{4}^{2-}$ & $1.3 \mathrm{E} 1$ & Hepler and Olofsson (1975) \\
$\mathrm{Hg}^{2+}+\mathrm{Br}^{-} \rightleftharpoons \mathrm{HgBr}^{+}$ & $1.1 \mathrm{E} 9$ & Hepler and Olofsson (1975) \\
$\mathrm{HgBr}^{+}+\mathrm{Br}^{-} \rightleftharpoons \mathrm{HgBr}_{2}$ & $2.5 \mathrm{E} 8$ & Hepler and Olofsson (1975) \\
$\mathrm{HgBr}_{2}+\mathrm{Br}^{-} \rightleftharpoons \mathrm{HgBr}_{3}^{-}$ & $1.5 \mathrm{E} 2$ & Hepler and Olofsson (1975) \\
$\mathrm{HgBr}_{3}^{-}+\mathrm{Br}^{-} \rightleftharpoons \mathrm{HgBr}_{4}^{2-}$ & $2.3 \mathrm{E} 1$ & Hepler and Olofsson (1975) \\
$\mathrm{HgOH}^{+}+\mathrm{Cl}^{-} \rightleftharpoons \mathrm{HgOHCl}^{2}$ & $2.69 \mathrm{E} 7$ & see note \\
\hline
\end{tabular}

${ }^{\mathrm{a}}$ value as cited by Pan and Carmichael (2005)

Table 5. Henry's law coefficients $k_{\mathrm{H}}$.

\begin{tabular}{lll}
\hline reaction & $k_{\mathrm{H}}[\mathrm{M} / \mathrm{atm}]$ & reference $^{\mathrm{a}}$ \\
\hline $\mathrm{Hg} \rightleftharpoons \mathrm{Hg}(\mathrm{aq})$ & 0.13 & see note $^{\mathrm{a}}$ \\
$\mathrm{HgO} \rightleftharpoons \mathrm{HgO}(\mathrm{aq})$ & $3.2 \mathrm{E} 6$ & see note $^{\mathrm{b}}$ \\
$\mathrm{HgCl}_{2} \rightleftharpoons \mathrm{HgCl}_{2}(\mathrm{aq})$ & $2.4 \mathrm{E} 7$ & see note $^{\mathrm{b}}$ \\
$\mathrm{HgBr}_{2} \rightleftharpoons \mathrm{HgBr}_{2}(\mathrm{aq})$ & $2.4 \mathrm{E} 7$ & see note $^{\mathrm{c}}$ \\
$\mathrm{ClHgBr} \rightleftharpoons \mathrm{ClHgBr}(\mathrm{aq})$ & $2.4 \mathrm{E} 7$ & see note $^{\mathrm{c}}$ \\
$\mathrm{BrHgOBr} \rightleftharpoons \mathrm{BrHgOBr}(\mathrm{aq})$ & $2.4 \mathrm{E} 7$ & see note $^{\mathrm{c}}$ \\
$\mathrm{ClHgOBr} \rightleftharpoons \mathrm{ClHgOBr}(\mathrm{aq})$ & $2.4 \mathrm{E} 7$ & see note $^{\mathrm{c}}$ \\
\hline
\end{tabular}

${ }^{a}$ value as cited by Schroeder and Munthe (1998)

$\mathrm{b}_{\text {value as cited by Shon et al. (2005) }}$

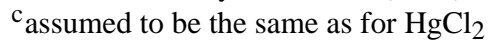

is slow, its contribution should be small (Xiao et al., 1994). The reduction of aqueous $\mathrm{Hg}^{2+}$ by $\mathrm{S}$ (IV) was also reported to have a small rate constant (Munthe et al., 1991; van Loon et al., 2000). After depletion of aqueous S(IV), the reaction of $\mathrm{HO}_{2}$ with $\mathrm{Hg}$ may be the only significant aqueous reduction balancing $\mathrm{Hg}^{0}$ oxidation (Lin and Pehkonen, 1998; Lin et al., 2006). However, there is no literature reporting a direct kinetic study of the $\mathrm{Hg}^{2+}+\mathrm{HO}_{2}$ reaction. Pehkonen and Lin (1998) proposed a two-step reduction of $\mathrm{Hg}^{2+}$ by $\mathrm{HO}_{2}$ as an important reducing pathway. For the second step, we assume the same value as for $\mathrm{Hg}^{+}+\mathrm{OH}$. It should be noted that according to Gardfeldt and Jonsson (2003), $\mathrm{Hg}^{2+}$ will not be reduced by $\mathrm{HO}_{2}$ under ambient conditions.

\subsection{Aqueous-phase equilibria}

Aqueous $\mathrm{Hg}^{2+}$ can form a wide variety of complexes with softer ligands such as $\mathrm{Cl}^{-}, \mathrm{Br}^{-}$, and $\mathrm{SO}_{3}^{2-}$ which have a sig-
Table 6. Initial gas-phase mixing ratios.

\begin{tabular}{lll}
\hline species & \multicolumn{2}{l}{ initial value } \\
\hline $\mathrm{O}_{3}$ & 30 & $\mathrm{nmol} / \mathrm{mol}$ \\
$\mathrm{Hg}$ & 0.168 & $\mathrm{pmol} / \mathrm{mol}$ \\
$\mathrm{NO}$ & 10 & $\mathrm{pmol} / \mathrm{mol}$ \\
$\mathrm{NO}_{2}$ & 10 & $\mathrm{pmol} / \mathrm{mol}$ \\
$\mathrm{SO}_{2}$ & 100 & $\mathrm{pmol} / \mathrm{mol}$ \\
$\mathrm{C}_{2} \mathrm{H}_{6}$ & 2000 & $\mathrm{pmol} / \mathrm{mol}$ \\
$\mathrm{C}_{2} \mathrm{H}_{4}$ & 26 & $\mathrm{pmol} / \mathrm{mol}$ \\
$\mathrm{C}_{2} \mathrm{H}_{2}$ & 329 & $\mathrm{pmol} / \mathrm{mol}$ \\
\hline
\end{tabular}

nificant impact on the reaction kinetics. Compared to these inorganic ligands, the concentrations of organic ligands are low and thus not considered here. Formation of $\mathrm{Hg}^{2+}$ complexes are treated as chemical equilibria since $\mathrm{Hg}^{2+}$ has a very rapid water exchange rate in aqueous solutions (Brezonik, 1994) (Table 4).

As suggested by Lin and Pehkonen (1997) and Lin and Pehkonen (1998), the total concentration of ligands and the $\mathrm{pH}$ of atmospheric droplets are important factors affecting $\mathrm{Hg}^{2+}$ speciation. At low $\mathrm{S}(\mathrm{IV})$ concentrations, mercury chloride complexes $\left(\mathrm{HgCl}_{2}, \mathrm{HgCl}_{3}^{-}\right.$, and $\left.\mathrm{HgCl}_{4}^{2-}\right)$ dominante (Lin et al., 2006), while at high S(IV) concentrations, the dominant complex is $\mathrm{Hg}\left(\mathrm{SO}_{3}\right)_{2}^{2-}$ (Lin and Pehkonen, 1998; Lin et al., 2006). Below pH 5.5, $\mathrm{OH}^{-}$concentrations are low and cannot form hydroxide complexes with $\mathrm{Hg}^{2+}$. In the marine boundary layer or polar regions, the contribution of bromide $\left(\mathrm{Br}^{-}\right)$complexes can be significant. Since the lifetime of aqueous S(IV) is only a few hours, chloride and bromide may be the most important ligands (Lin et al., 2006). 
Table 7. Summary of base run and sensitivity studies S1 to S20. Values that differ from the BASE run are shown in red.

\begin{tabular}{|c|c|c|c|c|c|c|c|c|}
\hline \# & $\begin{array}{l}\text { used } \\
\text { in Figs. }\end{array}$ & $\begin{array}{r}k_{\mathrm{Hg}+\mathrm{Br}} \\
{\left[\mathrm{cm}^{3} \text { molecule }^{-1}\right.} \\
\left.\mathrm{s}^{-1}\right]\end{array}$ & $\begin{array}{r}k_{\mathrm{Hg}+\mathrm{BrO}} \\
{\left[\mathrm{cm}^{3} \text { molecule }^{-1}\right.} \\
\left.\mathrm{s}^{-1}\right]\end{array}$ & $\begin{array}{r}\mathrm{T} \\
{[\mathrm{K}]}\end{array}$ & $\begin{array}{r}\mathrm{CaCO}_{3} \\
\text { precip. } \\
\%\end{array}$ & $\begin{array}{l}\mathrm{Cl} \\
\text { chemistry } \\
\text { on/off }\end{array}$ & $\begin{array}{l}\mathrm{Br} \\
\text { chemistry } \\
\text { on/off }\end{array}$ & $\begin{array}{r}\text { initial } \\
\mathrm{SO}_{2} \\
\mathrm{pmol} / \mathrm{mol}\end{array}$ \\
\hline BASE & $2,3,4,7,9$ & $3 E-13$ & $1 \mathrm{E}-15$ & 240 & 30 & $\mathrm{ON}$ & $\mathrm{ON}$ & 100 \\
\hline S1 & 5 & - & - & 240 & 30 & $\mathrm{ON}$ & OFF & 100 \\
\hline S2 & 5 & - & - & 240 & 30 & OFF & OFF & 100 \\
\hline S3 & 6 & 1E-14 & 0 & 240 & 30 & $\mathrm{ON}$ & $\mathrm{ON}$ & 100 \\
\hline S4 & 6 & 1E-13 & 0 & 240 & 30 & $\mathrm{ON}$ & $\mathrm{ON}$ & 100 \\
\hline S5 & 6,7 & $3 \mathrm{E}-13$ & $\mathbf{0}$ & 240 & 30 & $\mathrm{ON}$ & $\mathrm{ON}$ & 100 \\
\hline S6 & 6 & 1E-12 & 0 & 240 & 30 & $\mathrm{ON}$ & $\mathrm{ON}$ & 100 \\
\hline S7 & 6 & $3.2 \mathrm{E}-12$ & 0 & 240 & 30 & $\mathrm{ON}$ & $\mathrm{ON}$ & 100 \\
\hline S8 & 6,7 & 0 & $1 \mathrm{E}-15$ & 240 & 30 & $\mathrm{ON}$ & $\mathrm{ON}$ & 100 \\
\hline S9 & 6 & 0 & 5E-15 & 240 & 30 & $\mathrm{ON}$ & $\mathrm{ON}$ & 100 \\
\hline $\mathrm{S} 10$ & 6,7 & 0 & $1 \mathrm{E}-14$ & 240 & 30 & $\mathrm{ON}$ & $\mathrm{ON}$ & 100 \\
\hline $\mathrm{S} 11$ & 6 & 0 & 5E-14 & 240 & 30 & $\mathrm{ON}$ & $\mathrm{ON}$ & 100 \\
\hline $\mathrm{S} 12$ & 6 & 0 & 1E-13 & 240 & 30 & $\mathrm{ON}$ & $\mathrm{ON}$ & 100 \\
\hline $\mathrm{S} 13$ & 7 & 0 & 0 & 240 & 30 & $\mathrm{ON}$ & $\mathrm{ON}$ & 100 \\
\hline $\mathrm{S} 14$ & 7 & 3E-14 & 0 & 240 & 30 & $\mathrm{ON}$ & $\mathrm{ON}$ & 100 \\
\hline $\mathrm{S} 15$ & $8,9,10$ & $3 E-13$ & $1 \mathrm{E}-15$ & 240 & 0 & $\mathrm{ON}$ & ON & 100 \\
\hline S16 & 9 & $3 \mathrm{E}-13$ & $1 \mathrm{E}-15$ & 240 & 0 & $\mathrm{ON}$ & $\mathrm{ON}$ & 1000 \\
\hline S17 & 9 & $3 \mathrm{E}-13$ & $1 \mathrm{E}-15$ & 240 & 10 & $\mathrm{ON}$ & $\mathrm{ON}$ & 100 \\
\hline S20 & 10 & $3 \mathrm{E}-13$ & $1 \mathrm{E}-15$ & 298 & 0 & $\mathrm{ON}$ & $\mathrm{ON}$ & 100 \\
\hline
\end{tabular}

\subsection{Gas-aqueous phase exchange}

Equilibration towards Henry's law is calculated using the mass-transfer coefficients $\left(k_{\mathrm{mt}}\right)$ according to Schwartz (1986). The accommodation coefficient was assumed to be $\alpha=0.1$ for all mercury species, and the Henry's law coefficients are listed in Table 5. Mercury compounds have vapor pressures orders of magnitude lower than that of elemental mercury and belong to the group of semivolatiles.

\section{Results and discussion}

The conditions of our model runs are similar to those in Sander et al. (2006). The model starts on 31 March with initial gas-phase mixing ratios as shown in Table 6 . The temperature is set to $T=240 \mathrm{~K}$. Photolysis rate coefficients are calculated for a latitude of $82^{\circ} \mathrm{N}$. The chemistry of background sulfate aerosol is switched on in the model runs. Sea salt particles ( $2 \mu \mathrm{m}$ radius) are injected into the air on 4 April (i.e. after a spin up of 4 days). They are composed of wellmixed, liquid, concentrated sea water ( $c=5 \mathrm{~mol} / \mathrm{L})$, assuming that $30 \%$ of the carbonate has precipitated before particle formation. The initial liquid water content (LWC) of the model aerosol is $5 \times 10^{-10} \mathrm{~m}^{3} / \mathrm{m}^{3}$, and it decays exponentially with a lifetime of 3 days. The main features of this BASE run, and also of several sensitivity studies (as described in the sections below) are summarized in Table 7 .

After injection into the air, the aerosol $\mathrm{pH}$ drops abruptly to about 3. The so-called "bromine explosion" starts and the levels of $\mathrm{BrO}$ and $\mathrm{Br}$ increase quickly. Sea salt aerosol is depleted in $\mathrm{Br}^{-}$during this period. After 2 days both $\mathrm{Hg}$ and $\mathrm{O}_{3}$ are thoroughly depleted.

\subsection{Model-calculated speciation of mercury compounds}

Potential oxidation products of gaseous $\mathrm{Hg}$ include $\mathrm{HgO}$, $\mathrm{HgCl}, \mathrm{HgCl}_{2}, \mathrm{HgBr}, \mathrm{HgBr}_{2}, \mathrm{ClHgBr}, \mathrm{BrHgOBr}$ and $\mathrm{ClHgOBr}$. Their modeled levels during the AMDE are shown in Fig. 2. $\mathrm{HgCl}$ and $\mathrm{HgBr}$ are intermediates and only found during the first two days. $\mathrm{HgO}$ also disappears after two days. The major $\mathrm{Hg}$-containing product is $\mathrm{BrHgOBr}$. The maxima of $\mathrm{HgCl}_{2}$ and $\mathrm{HgBr}_{2}$ at the end of the AMDE only reach $1.4 \times 10^{-5}$ and $0.012 \mathrm{pmol} / \mathrm{mol}$, respectively. Our modeled speciation is in agreement with results by Calvert and Lindberg (2003). After two days, the total of oxidized gaseous mercury peaks around $0.1 \mathrm{pmol} / \mathrm{mol}$. Our model predictions are consistent with ambient observations at Barrow. Lindberg et al. (2002) reported RGM peaks of more than $0.9 \mathrm{ng} / \mathrm{m}^{3}\left(1 \mathrm{ng} / \mathrm{m}^{3}\right.$ equals $\left.0.11 \mathrm{pmol} / \mathrm{mol}\right)$ during AMDEs in this region. However, our numbers are larger than some observations at $\mathrm{Ny}$-Ålesund with peaks at about $0.25 \mathrm{ng} / \mathrm{m}^{3}$ (Aspmo et al., 2005). The reason for the difference between the simulation and some field observations is not entirely clear. A potential explanation may be that our model represents locally occurring $\mathrm{Hg}$ depletion chemistry, while some field observations may represent transport of an airmass already depleted in GEM and RGM. 


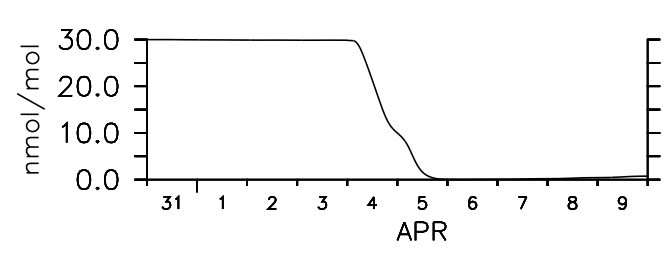

$\mathrm{O}_{3}$

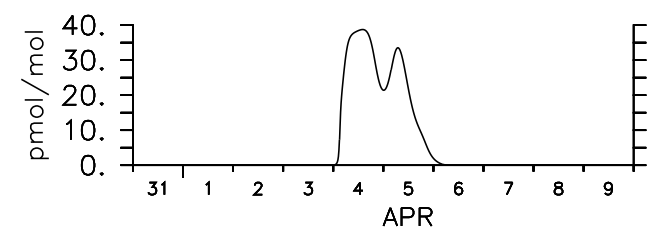

BrO

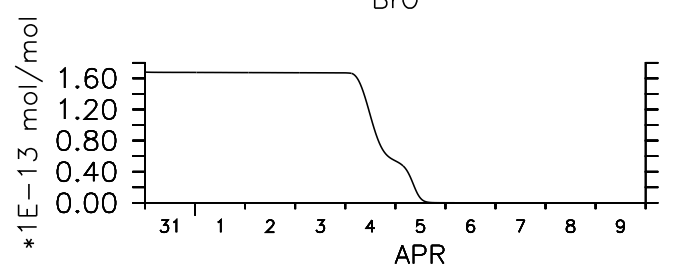

$\mathrm{Hg}$

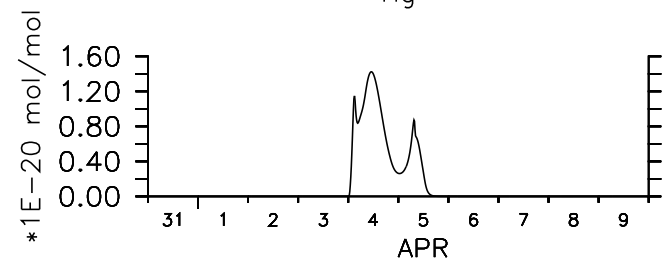

$\mathrm{HgCl}$

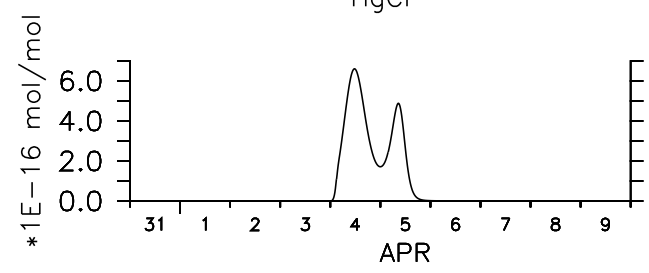

$\mathrm{HgBr}$

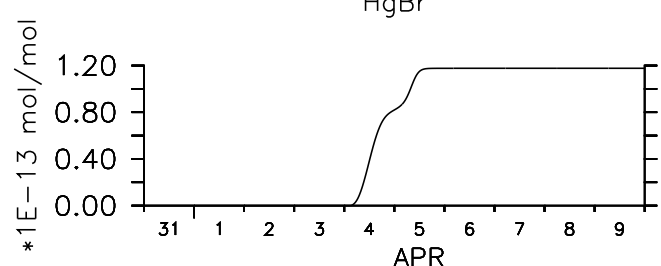

$\mathrm{BrHgOBr}$

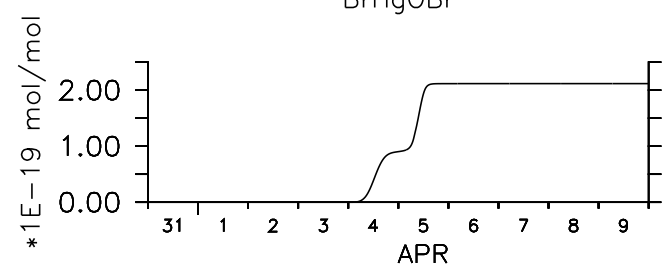

$\mathrm{ClHgBr}$

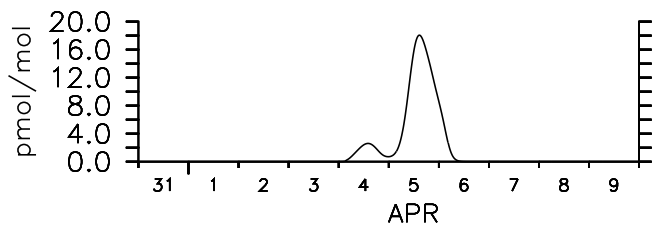

$\mathrm{Br}$

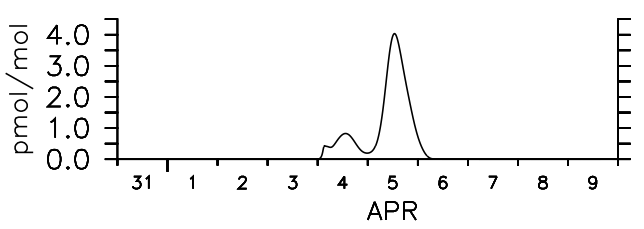

$\mathrm{HOBr}$

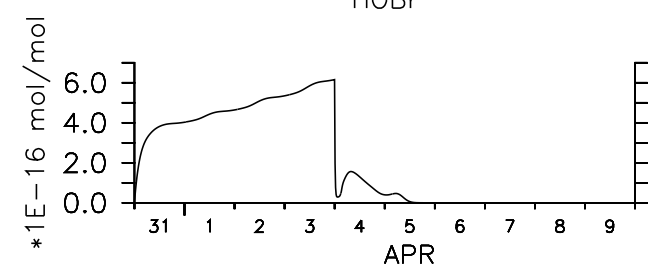

$\mathrm{HgO}$

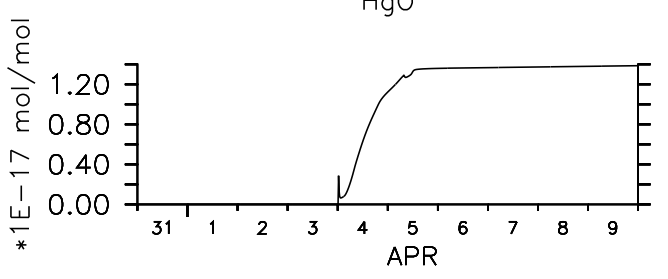

$\mathrm{HgCl}_{2}$
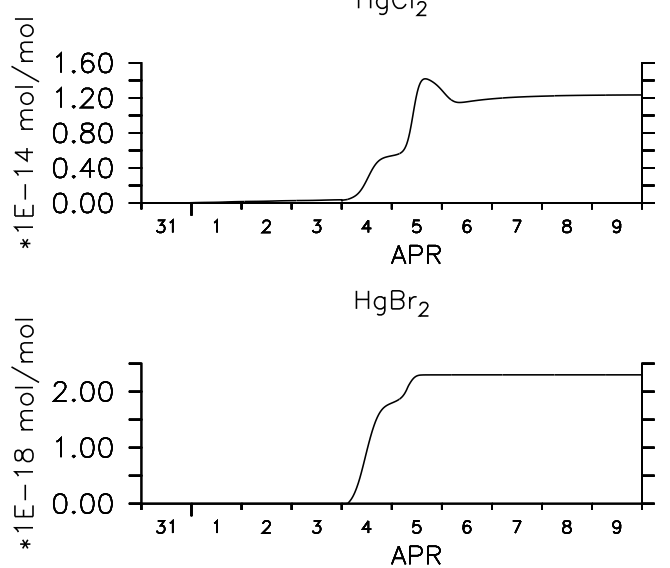

$\mathrm{ClHgOBr}$

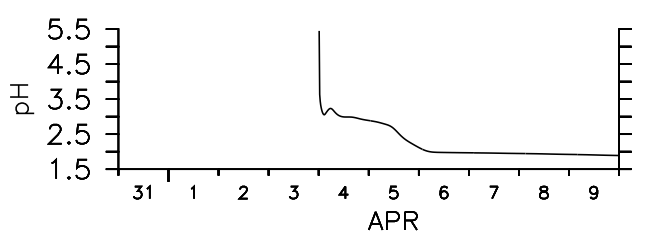

$\mathrm{pH}(\mathrm{cs})$

Fig. 2. Temporal evolution of model-calculated gas-phase ozone, bromine and mercury species in the BASE run. Also shown is the aerosol $\mathrm{pH}$. 

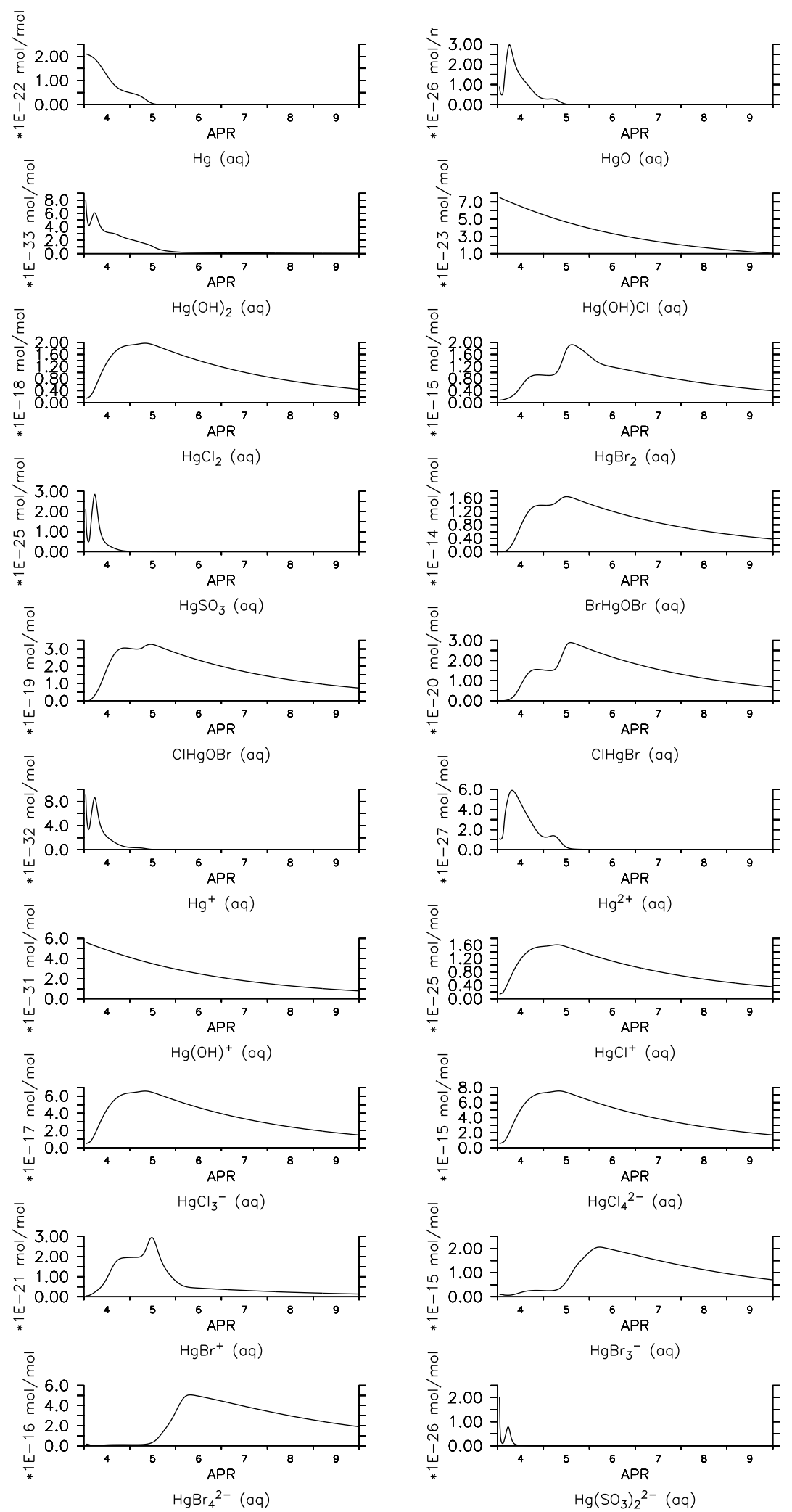

Fig. 3. Temporal evolution of model-calculated aqueous-phase mercury species in the BASE run (expressed as mixing ratios). 

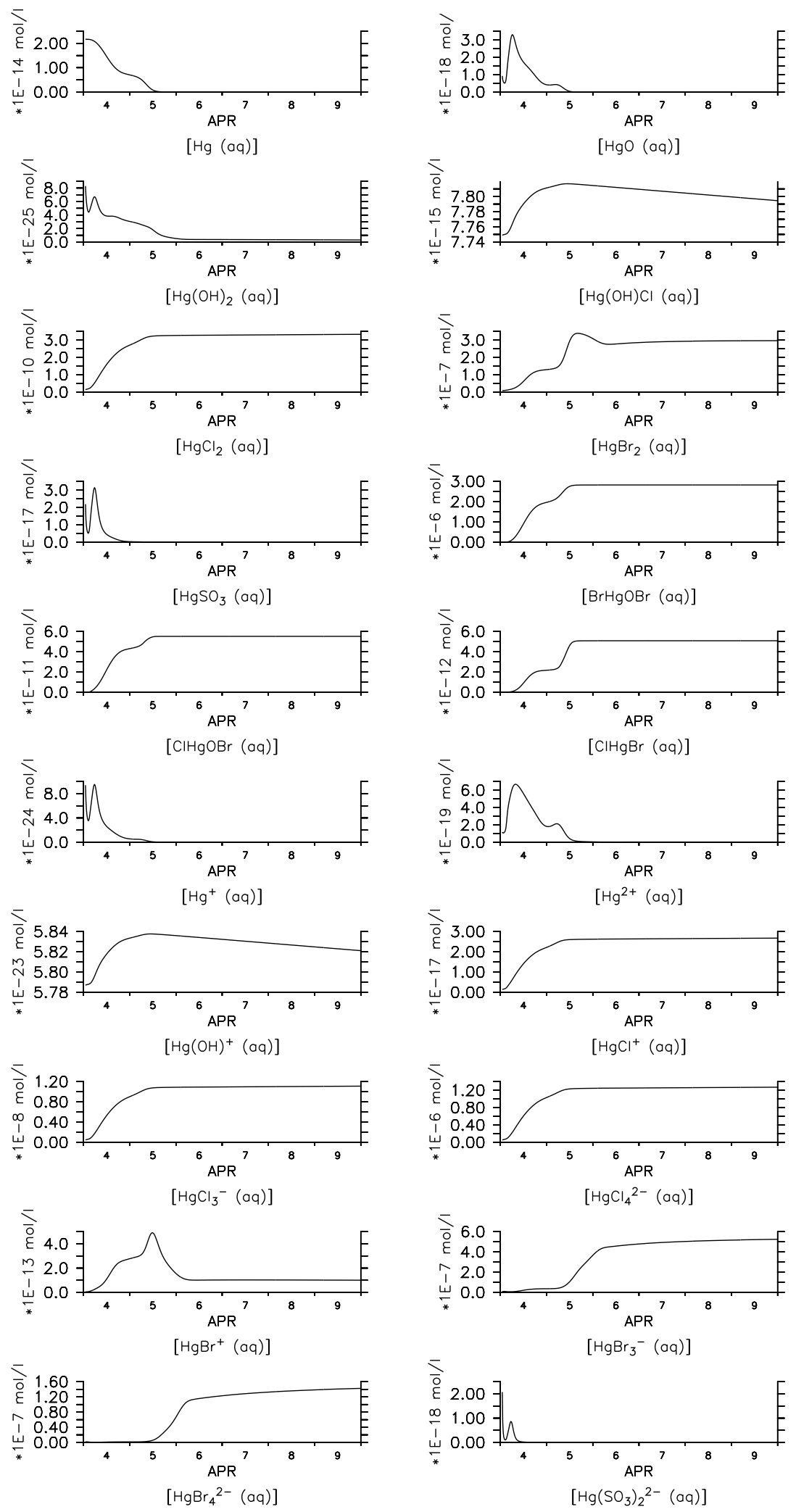

Fig. 4. Temporal evolution of model-calculated aqueous-phase mercury species (aqueous concentrations in mol/L) in the BASE run. 

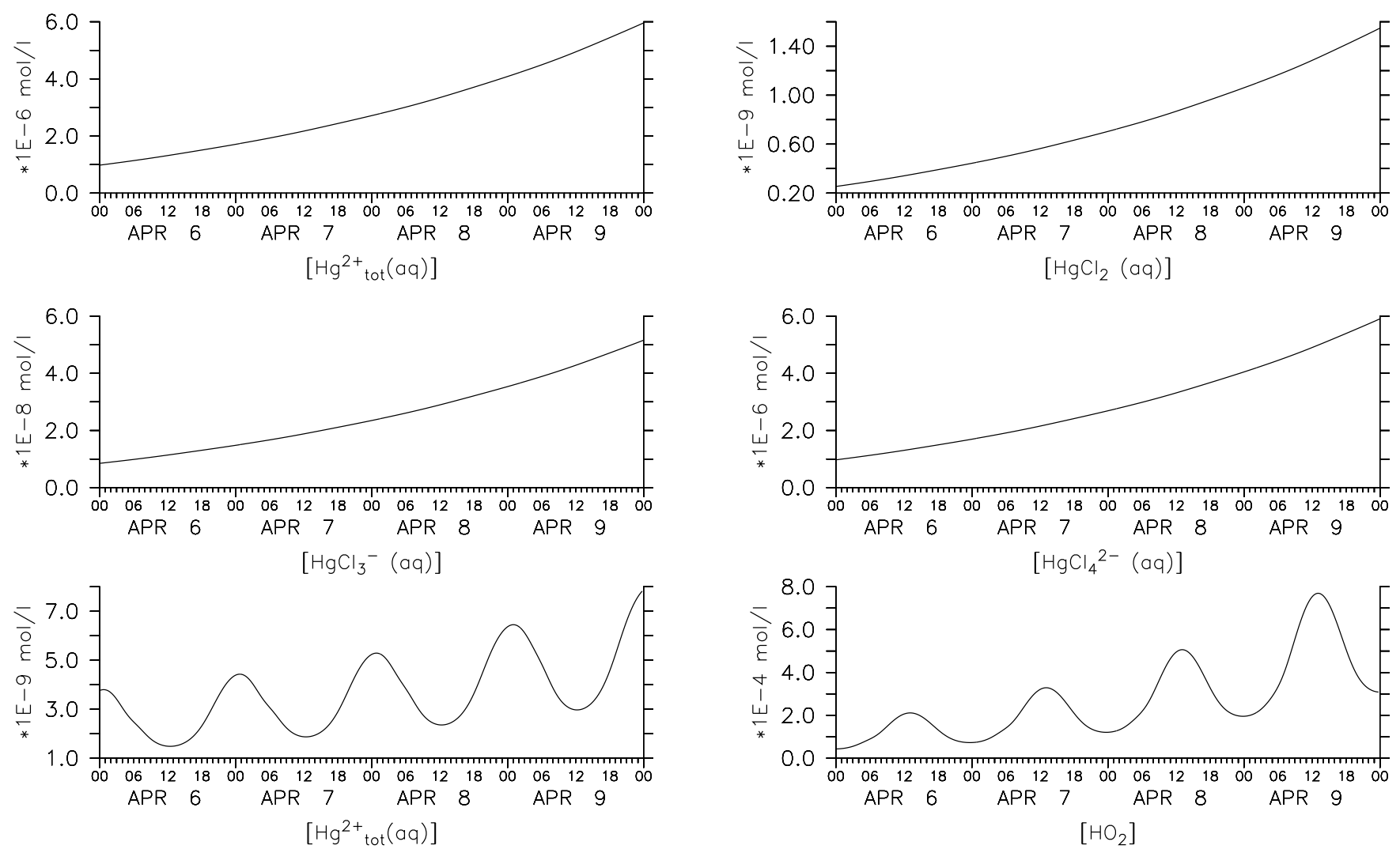

Fig. 5. Total concentration of aqueous-phase divalent mercury complexes $\left(\mathrm{Hg}_{\text {tot }}^{2+}\right)$. Top rows: sensitivity study $\mathrm{S} 1$ without $\mathrm{Br}$ chemistry. Here, $\mathrm{Hg}_{\text {tot }}^{2+}$ is virtually identical to $\mathrm{HgCl}_{4}^{2-}$. Bottom row: sensitivity study $\mathrm{S} 2$ without any halogen chemistry. Here, an anticorrelation to $\mathrm{HO}_{2}$ can be seen.

The main mercury species in the aqueous phase are $\mathrm{BrHgOBr}, \mathrm{HgCl}_{4}^{2-}, \mathrm{HgBr}_{2}, \mathrm{HgBr}_{3}^{-}$, and $\mathrm{HgBr}_{4}^{2-}$. At the beginning of the AMDE, the concentrations of chlorine complexes increase quickly and peak after one day. The concentration of $\mathrm{HgBr}_{2}$ increases faster than that of the other bromine complexes during the first day and peaks when GEM reaches zero. After that, their amount in the atmosphere decreases (Fig. 3, in $\mathrm{mol} / \mathrm{mol}$ ) due to the loss of sea salt aerosols, while their aqueous-phase concentrations reach equilibria and remain constant (Fig. 4, in mol/L).

The main sulfur complexes are $\mathrm{HgSO}_{3}$ and $\mathrm{Hg}\left(\mathrm{SO}_{3}\right)_{2}^{2-}$. Their concentrations are very low and their diurnal cycles after AMDEs are controlled by the variation of $\mathrm{SO}_{3}^{2-}$ concentrations. In contrast to the study by Pan and Carmichael (2005), the sum of all divalent mercury complexes $\left(\mathrm{Hg}_{\text {tot }}^{2+}\right)$ does not display a diurnal cycle. We have performed further sensitivity tests to find the reason for this difference. As shown in Fig. 5 (top rows), when bromine chemistry was switched off, neither $\mathrm{Hg}_{\text {tot }}^{2+}$ nor $\mathrm{HgCl}_{2}$ show a diurnal cycle. This is due to the high levels of $\mathrm{Cl}^{-}$in the sea-salt aerosol of our model. When both chlorine and bromine chemistry were switched off, $\mathrm{Hg}_{\text {tot }}^{2+}$ concentrations display the same cy- cle as calculated by Pan and Carmichael (2005), which is controlled by the oxygen-hydrogen photochemical reactions that produce $\mathrm{HO}_{2}$ radicals in the liquid phase (Fig. 5, bottom row).

To the best of our knowledge, this is the first model study of atmospheric mercury speciation in both the gas and the aqueous phase including bromine chemistry. However, our results can only be considered preliminary because we had to use estimates for several Henry's law coefficients. Still, we hope that our simulations can provide first clues about the mercury compounds deposited to the snowpack in polar regions.

\subsection{The reactions of $\mathrm{Hg}$ with $\mathrm{Br}$ and $\mathrm{BrO}$}

Both $\mathrm{Br}$ and $\mathrm{BrO}$ are considered potentially important reactants responsible for the observed loss of GEM in polar regions during bromine explosions. However, the kinetics are not well-known, and a wide range of rate coefficients has been published for their reactions. Holmes et al. (2006) compiled literature values of the rate coefficient $k_{\mathrm{Hg}+\mathrm{Br}}$. At $1 \mathrm{~atm}$ and $298 \mathrm{~K}$, it is between $3.0-9.7 \times 10^{-13}$ (Donohoue et al., 2006) 


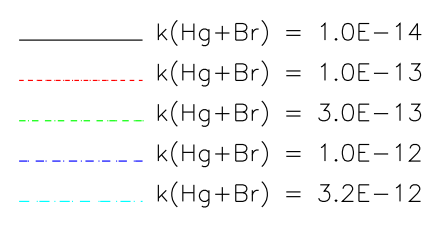

$k(\mathrm{Hg}+\mathrm{BrO})=1 \mathrm{E}-15$

$k(\mathrm{Hg}+\mathrm{BrO})=5 \mathrm{E}-15$

$k(\mathrm{Hg}+\mathrm{BrO})=1 \mathrm{E}-14$

$k(\mathrm{Hg}+\mathrm{BrO})=5 \mathrm{E}-14$

$k(\mathrm{Hg}+\mathrm{BrO})=1 \mathrm{E}-13$

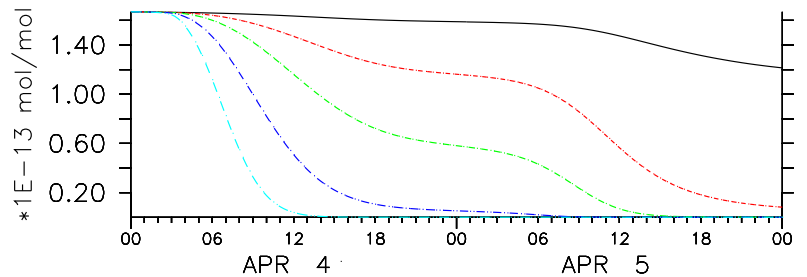

$\mathrm{Hg}$

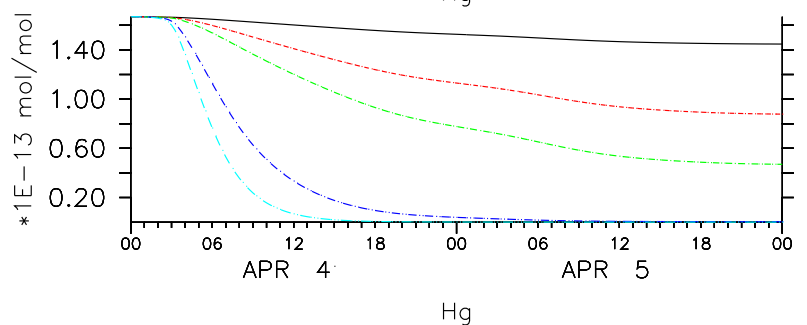

$\mathrm{Hg}$

Fig. 6. Changes in the GEM depletion rates with respect to different $k_{\mathrm{Hg}+\mathrm{Br}}$ and $k_{\mathrm{Hg}+\mathrm{BrO}}$ values (unit $=\mathrm{cm}^{3}$ molecule ${ }^{-1} \mathrm{~s}^{-1}$ ).
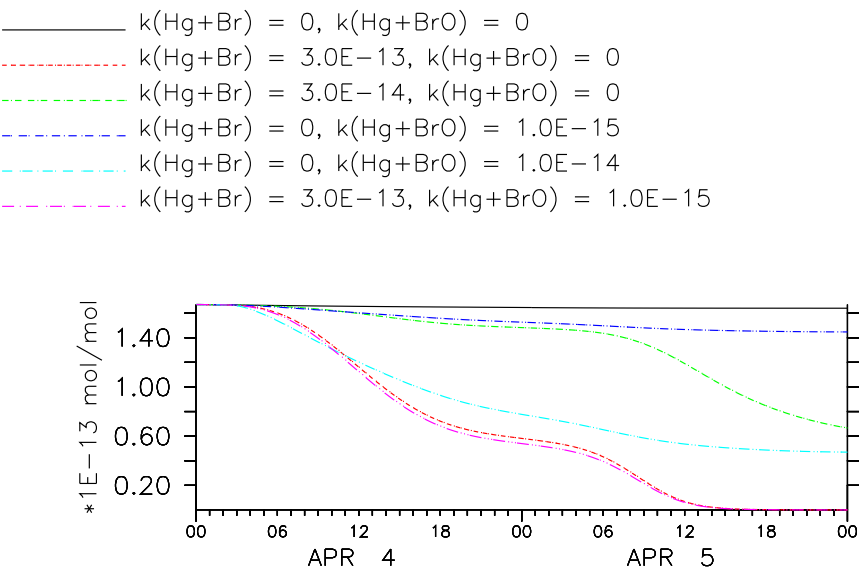

$\mathrm{Hg}$

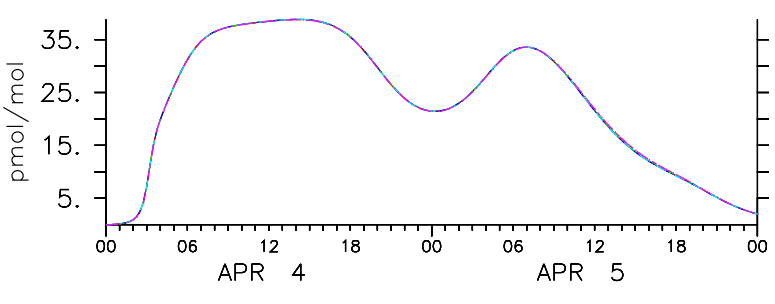

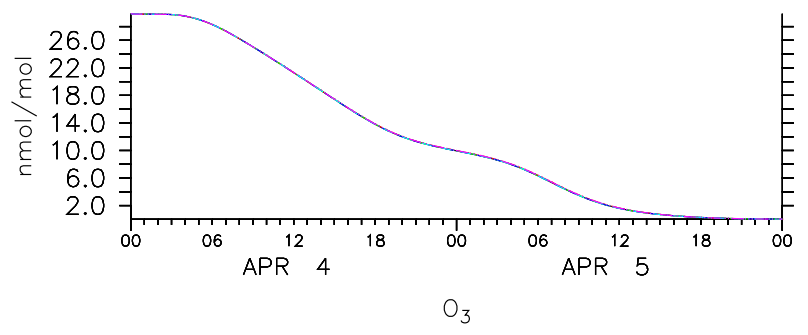
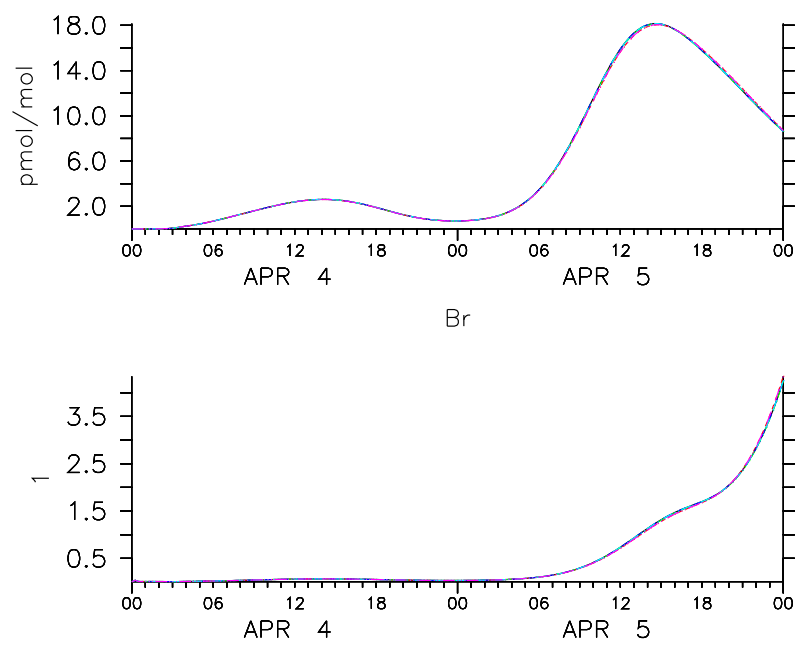

$\mathrm{Br} / \mathrm{BrO}$

Fig. 7. The role of $\mathrm{BrO}+\mathrm{Hg}$ and $\mathrm{Br}+\mathrm{Hg}$ as a function of the $\mathrm{Br} / \mathrm{BrO}$ ratio $\left(k\right.$ in $\mathrm{cm}^{3}$ molecule $\left.{ }^{-1} \mathrm{~s}^{-1}\right)$.

and $3.2 \times 10^{-12} \mathrm{~cm}^{3}$ molecule ${ }^{-1} \mathrm{~s}^{-1}$ (Ariya et al., 2002). There is limited information about its temperature- and pressure-dependence. Khalizov et al. (2003) and Goodsite et al. (2004) reported values of $1.0 \times 10^{-12} \exp (209 \mathrm{~K} / T)$ and $1.1 \times 10^{-12}(T / 298 \mathrm{~K})^{-2.37} \mathrm{~cm}^{3}$ molecule ${ }^{-1} \mathrm{~s}^{-1}$, respec- tively, at $1 \mathrm{~atm}$. Regarding the reaction $\mathrm{Hg}+\mathrm{BrO}$, Holmes et al. (2006) and Shepler et al. (2007) argued, based upon theoretical calculations, that it is unlikely to occur in the atmosphere as it is endothermic and has a large energy barrier. However, laboratory measurements by Raofie and 

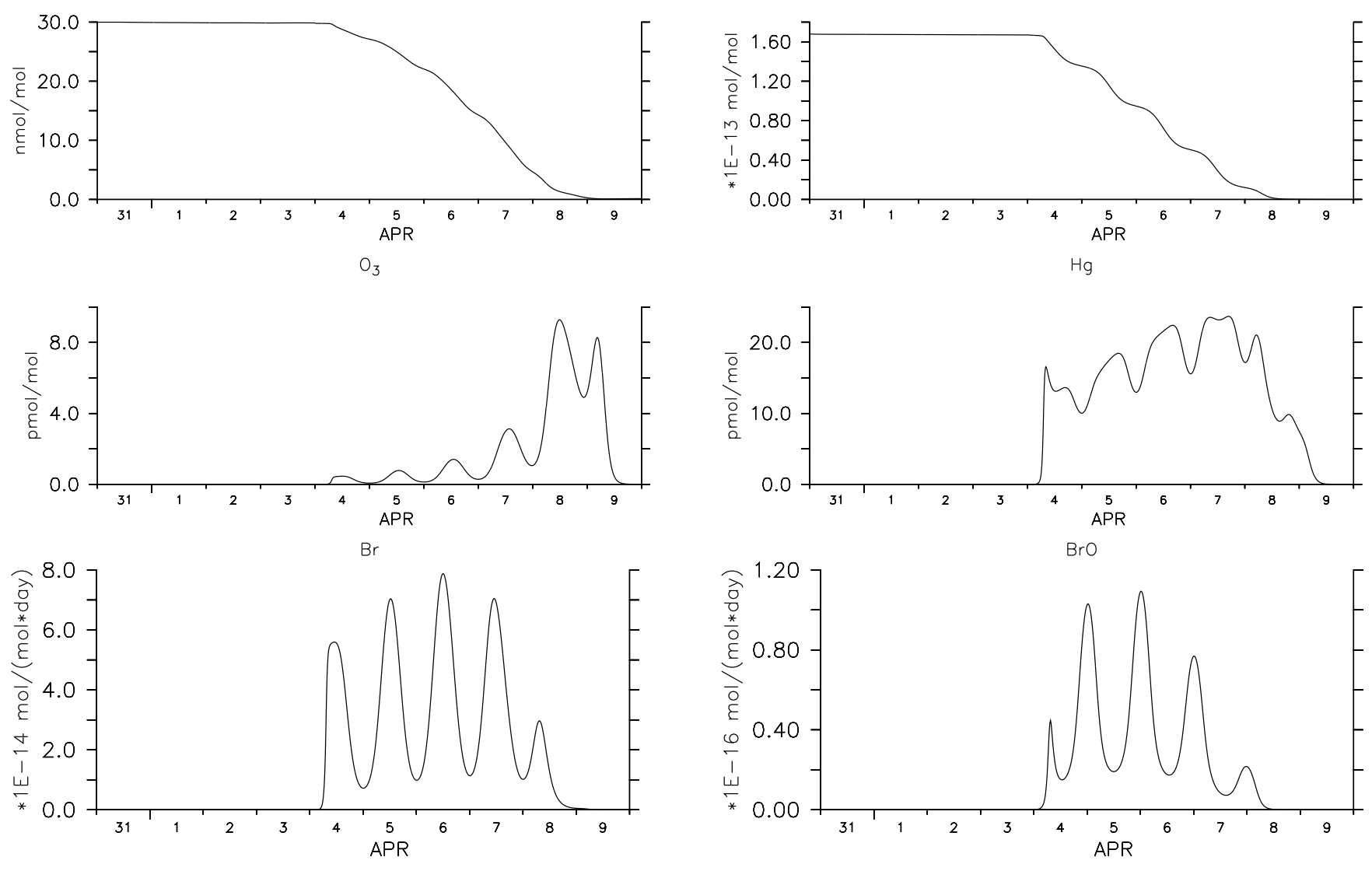

$\mathrm{Hg}+\mathrm{Br} \rightarrow \mathrm{HgBr}$

$\mathrm{Hg}+\mathrm{Br} 2 \rightarrow \mathrm{HgBr} 2$

Fig. 8. Time series of $\mathrm{O}_{3}, \mathrm{Hg}, \mathrm{Br}$, and $\mathrm{BrO}$ during an ODE that last several days (sensitivity study S15, see Table 7). Also shown are the GEM depletion rates for $k_{\mathrm{Hg}+\mathrm{Br}}=3.0 \times 10^{-13}$ and $k_{\mathrm{Hg}+\mathrm{BrO}}=1.0 \times 10^{-15} \mathrm{~cm}^{3}$ molecule $\mathrm{s}^{-1}$, respectively.

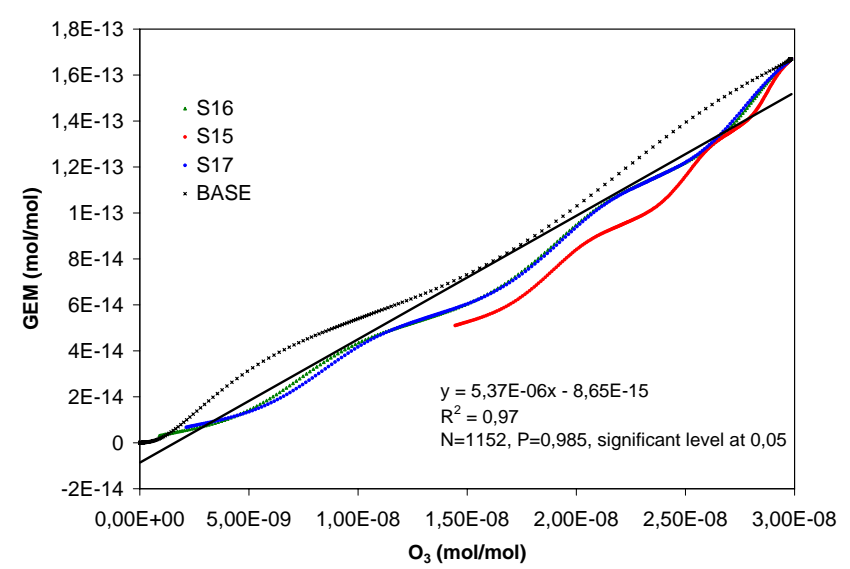

Fig. 9. Correlation between GEM and $\mathrm{O}_{3}$ in the BASE run and in sensitivity studies S15, S16, and S17. See Table 7 for a description of the model runs.
Ariya (2003) showed that $k_{\mathrm{Hg}+\mathrm{BrO}}$ is between $10^{-15}$ and $10^{-13} \mathrm{~cm}^{3}$ molecule $\mathrm{s}^{-1} \mathrm{~s}^{-1}$. Further experiments identified $\mathrm{HgBr}, \mathrm{HgBrO} / \mathrm{HgOBr}$, and $\mathrm{HgO}$ as reaction products (Raofie and Ariya, 2004). To test the possible importance of $\mathrm{Hg}+\mathrm{Br}$ and $\mathrm{Hg}+\mathrm{BrO}$ in our model, we have performed several sensitivity runs, varying their rate coefficients.

In a first series of simulations, the reaction $\mathrm{Hg}+\mathrm{BrO}$ is switched off, and $k_{\mathrm{Hg}+\mathrm{Br}}$ is varied (top graph in Fig. 6). With $k_{\mathrm{Hg}+\mathrm{Br}}=1.0 \times 10^{-14}, 1.0 \times 10^{-13}, 3.0 \times 10^{-13}, 1.0 \times 10^{-13}$, $3.2 \times 10^{-12} \mathrm{~cm}^{3}$ molecules ${ }^{-1} \mathrm{~s}^{-1}$, a fraction of $5.0 \%, 30 \%$, $65 \%, 97 \%$ and $100 \%$ GEM, respectively, has been depleted after one day. In a second series, the reaction $\mathrm{Hg}+\mathrm{Br}$ is switched off, and $k_{\mathrm{Hg}+\mathrm{BrO}}$ is varied (bottom graph in Fig. 6). With $k_{\mathrm{Hg}+\mathrm{BrO}}=1.0 \times 10^{-15}, 5.0 \times 10^{-15}, 1.0 \times 10^{-14}$, $5.0 \times 10^{-14}, 1.0 \times 10^{-13} \mathrm{~cm}^{3}$ molecules ${ }^{-1} \mathrm{~s}^{-1}$, a fraction of $7.0 \%, 29 \%, 52 \%, 97 \%$ and $100 \%$ GEM, respectively, has been depleted after one day.

Calvert and Lindberg (2003) suggested that if the rate coefficient $k_{\mathrm{Hg}+\mathrm{BrO}}$ is at least $1 / 30$ th to $1 / 450$ th of $k_{\mathrm{Hg}+\mathrm{Br}}$, then reaction of $\mathrm{Hg}$ with $\mathrm{BrO}$ can be as important as that with $\mathrm{Br}$ atoms. We performed further sensitivity runs to study the 

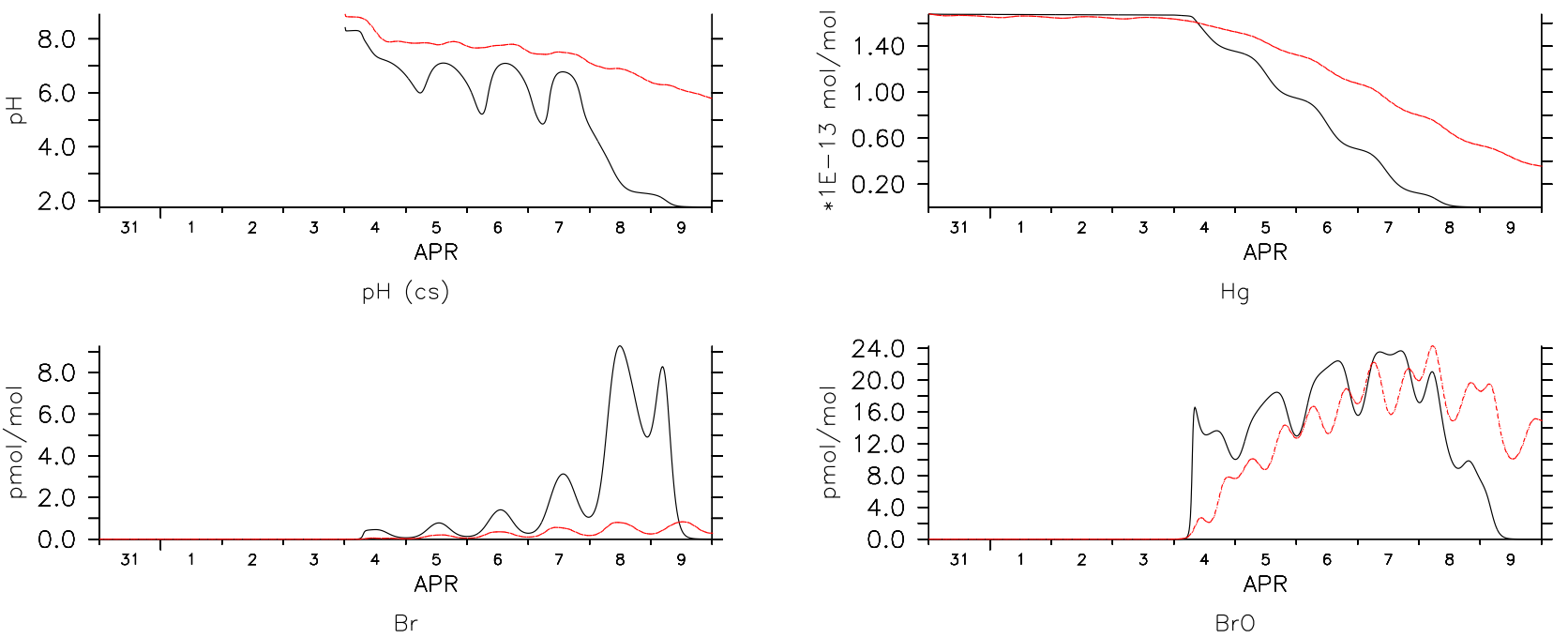

Fig. 10. The loss rate of $\mathrm{Hg}$ versus the different atmospheric temperature $(\mathrm{S} 15=$ black $=240 \mathrm{~K}, \mathrm{~S} 20=$ red $=298 \mathrm{~K})$ in a simulation without carbonate precipitation.

relative importance of these reactions. The results are shown in Fig. 7. In agreement with Calvert and Lindberg (2003), changing the mercury-related rate coefficients does not affect ozone or bromine species significantly. When both $k_{\mathrm{Hg}+\mathrm{Br}}$ and $k_{\mathrm{Hg}+\mathrm{BrO}}$ are zero (solid black line in Fig. 7), only $1.3 \%$ of the initial $\mathrm{Hg}$ is depleted during the first day, showing that in polar regions the reactions with $\mathrm{O}_{3}, \mathrm{OH}, \mathrm{H}_{2} \mathrm{O}_{2}, \mathrm{Br}_{2}, \mathrm{Cl}_{2}$, or $\mathrm{Cl}$ are not sufficient to deplete GEM. Also shown in the figure are the temporal evolution of $\mathrm{Br}$ and $\mathrm{BrO}$ during the ODE. Due to the ozone depletion, there is a steady increase in the ratio $\mathrm{Br} / \mathrm{BrO}$. Thus the relative importance of $\mathrm{Hg}+\mathrm{BrO}$ and $\mathrm{Hg}+\mathrm{Br}$ will shift towards the latter during the AMDE. In the beginning, when $\mathrm{O}_{3}$ decreases, the ratio is small with high levels of $\mathrm{BrO}$, while when $\mathrm{O}_{3}$ is low, less $\mathrm{BrO}$ is produced and subsequently the ratio increases.

This can be seen clearly in Fig. 8, which shows a model simulation of an ODE that lasts several days. The reaction $\mathrm{Hg}+\mathrm{Br}$ is important throughout the ODE, whereas the reaction $\mathrm{Hg}+\mathrm{BrO}$ slows down towards the end of the ODE, and never exceeds $10 \%$ of the total $\mathrm{Hg}$ loss rate. Both reactions show diurnal cycles with faster rates during the day. The diurnal cycle of $\mathrm{Hg}+\mathrm{Br}$ is more pronounced than that of $\mathrm{Hg}+\mathrm{BrO}$.

It is interesting to compare the loss rates of $\mathrm{Hg}$ and $\mathrm{O}_{3}$. Ebinghaus et al. (2002) reported Antarctic measurements with 15-min resolution and found a highly significant correlation between TGM and $\mathrm{O}_{3}$ at a lagtime of zero. In our model calculations, such a synchronous loss of GEM and ozone can best be reproduced when using $k_{\mathrm{Hg}+\mathrm{Br}}=3.0 \times 10^{-13}$ and $k_{\mathrm{Hg}+\mathrm{BrO}} \leq$ $1.0 \times 10^{-15} \mathrm{~cm}^{3}$ molecule ${ }^{-1} \mathrm{~s}^{-1}$. Using these rate coefficients for different mercury depletion scenarios, our model results show a significant correlation between mercury and ozone $\left(R^{2}=0.97\right.$, see Fig. 9).
With other values of $k_{\mathrm{Hg}+\mathrm{Br}}$, the rate of GEM depletion will either be faster or slower than that of $\mathrm{O}_{3}$ (Figs. 6 and 7).

In the model runs where the reaction $\mathrm{Hg}+\mathrm{Br}$ is switched off and the loss of GEM is due to reaction with BrO, a synchronized loss of $\mathrm{Hg}$ and $\mathrm{O}_{3}$ cannot be reproduced. When $k_{\mathrm{Hg}+\mathrm{BrO}}>1.0 \times 10^{-14} \mathrm{~cm}^{3} \mathrm{~s}^{-1}, \mathrm{Hg}$ loss is faster than that of ozone. With smaller values of $k_{\mathrm{Hg}+\mathrm{BrO}}$, the reaction becomes too slow towards the end of the ODE, when the concentration of $\mathrm{Hg}$ is small and the $\mathrm{Br} / \mathrm{BrO}$ ratio is high (Figs. 6 and 7). This implies that the contribution of $\mathrm{Hg}+\mathrm{BrO}$ to AMDEs is small.

\subsection{Effects of temperature}

Variations in temperature have a strong effect on reaction kinetics. For most reactions of mercury species, the temperature-dependence of the rate coefficients is not known. Still, models can be used to study indirect effects resulting from temperature effects on sulfur and halogen species.

Pan and Carmichael (2005) simulated the effect of temperature in the aqueous phase at night without halogens. In their model, low temperatures slow the oxidation of mercury in the aqueous phase and increase the time for the system to reach equilibrium. High temperatures favor the partitioning of $\mathrm{H}_{2} \mathrm{SO}_{3}$ into $\mathrm{SO}_{3}^{2-}$, and increase the oxidation rate of $\mathrm{SO}_{3}^{2-}$. The net result is that the $\mathrm{SO}_{3}^{2-}$ elimination speed is greater than its production speed. Therefore, they concluded that higher temperatures result in lower concentrations of $\mathrm{SO}_{3}^{2-}$, and favor the liquid-phase mercury oxidation reactions.

However, another effect that has to be considered is the temperature-dependence of the bromine explosion. Sander et al. (2006) simulated the role of temperature in the 
activation of bromine. They found that low temperatures favor the activation of reactive bromine due to a shift of the equilibrium between $\mathrm{BrCl}$ and $\mathrm{Br}_{2} \mathrm{Cl}^{-}$. An increase in bromine enhances the oxidation of $\mathrm{Hg}$.

To study these counteracting effects, we performed model runs at $T=298 \mathrm{~K}$ and $240 \mathrm{~K}$, as shown in Fig. 10. Consistent with the results from Pan and Carmichael (2005), the initial loss of $\mathrm{Hg}$ (before the bromine explosion) is faster at $298 \mathrm{~K}$. However, once the ODE starts, the loss of $\mathrm{Hg}$ is more pronounced at $240 \mathrm{~K}$ because of the higher concentrations of bromine species.

\section{Conclusions}

Investigating the chemistry of AMDEs with MECCA, we found that:

1. The reaction of $\mathrm{Hg}$ with $\mathrm{Br}$ dominates the loss of GEM throughout the depletion event. To explain the experimentally observed synchronous destruction of $\mathrm{Hg}$ and $\mathrm{O}_{3}$, the reaction rate of $\mathrm{Hg}+\mathrm{BrO}$ has to be much lower than that of $\mathrm{Hg}+\mathrm{Br}$. The synchronicity is best reproduced with rate coefficients at the lower limit of the literature values for both reactions, i.e. $k_{\mathrm{Hg}+\mathrm{Br}} \approx$ $3 \times 10^{-13}$ and $k_{\mathrm{Hg}+\mathrm{BrO}} \leq 1 \times 10^{-15} \mathrm{~cm}^{3}$ molecule $^{-1} \mathrm{~s}^{-1}$, respectively.

2. $\mathrm{BrHgOBr}$ is the most abundant reactive mercury species, both in the gas phase and in the aqueous phase. The aqueous-phase concentrations of $\mathrm{BrHgOBr}$ and mercury halide complexes $\left(\mathrm{HgX}_{2}, \mathrm{HgX}_{3}^{-}, \mathrm{HgX}_{4}^{2-}\right.$ with $\mathrm{X}=\mathrm{Br}, \mathrm{Cl}$ ) are several orders of magnitude larger than that of $\mathrm{Hg}\left(\mathrm{SO}_{3}\right)_{2}^{2-}$. Note, however, that these results depend on the assumed Henry's law coefficients, which need to be confirmed by measurements.

3. Considering chlorine chemistry outside depletion events (i.e. without bromine activation), the concentration of total divalent mercury in the sea-salt aerosol (concentrated solution droplets) is dominated by $\mathrm{HgCl}_{4}^{2-}$, does not exhibit a diurnal cycle, and is much higher than in dilute aqueous solution droplets, where it is dominated by $\mathrm{Hg}\left(\mathrm{SO}_{3}\right)_{2}^{2-}$ and negatively correlated with the $\mathrm{HO}_{2}$ radical concentration.

Acknowledgements. The Max-Planck Society and M. O. Andreae are gratefully acknowledged for support. Z.-Q. Xie acknowledges financial support from the Alexander von Humboldt Foundation and from the Chinese National Natural Science Foundation (grant no. 40776001) to visit Germany.

Edited by: J. W. Bottenheim

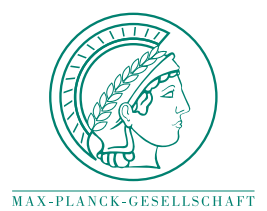

This Open Access Publication is financed by the Max Planck Society.

\section{References}

Ariya, P. A., Khalizov, A., and Gidas, A.: Reactions of gaseous mercury with atomic and molecular halogens: Kinetics, product studies, and atmospheric implications, J. Phys. Chem. A, 106, 7310-7320, 2002.

Ariya, P. A., Dastoor, A. P., Amyot, M., Schroeder, W. H., Barrie, L., Anlauf, K., Raofie, F., Ryzhkov, A., Davignon, D., Lalonde, J., and Steffen, A.: The Arctic: a sink for mercury, Tellus, 56B, 397-403, 2004.

Aspmo, K., Gauchard, P.-A., Steffen, A., Temme, C., Berg, T., Bahlmann, E., Banic, C., Dommergue, A., Ebinghaus, R., Ferrari, C., Pirrone, N., Sprovieri, F., and Wibetoe, G.: Measurements of atmospheric mercury species during an international study of mercury depletion events at Ny-Ålesund, Svalbard, spring 2003. How reproducible are our present methods?, Atmos. Environ., 39, 7607-7619, 2005.

Barrie, L. A., Bottenheim, J. W., Schnell, R. C., Crutzen, P. J., and Rasmussen, R. A.: Ozone destruction and photochemical reactions at polar sunrise in the lower Arctic atmosphere, Nature, 334, 138-141, 1988.

Berg, T., Sekkesæter, S., Steinnes, E., Valdal, A.-K., and Wibetoe, G.: Springtime depletion of mercury in the European Arctic as observed at Svalbard, Sci. Total Environ., 304, 43-51, 2003.

Bottenheim, J. W., Gallant, A. G., and Brice, K. A.: Measurements of $\mathrm{NO}_{y}$ species and $\mathrm{O}_{3}$ at $82^{\circ} \mathrm{N}$ latitude, Geophys. Res. Lett., 13, 113-116, 1986.

Brezonik, P. L. (Ed.): Chemical Kinetics and Process Dynamics in Aquatic Systems, CRC Press, Boca Raton, FL, 1994.

Calvert, J. G. and Lindberg, S. E.: A modeling study of the mechanism of the halogen-ozone-mercury homogeneous reactions in the troposphere during the polar spring, Atmos. Environ., 37, 4467-4481, 2003.

Calvert, J. G. and Lindberg, S. E.: Potential influence of iodinecontaining compounds on the chemistry of the troposphere in the polar spring. I. Ozone depletion, Atmos. Environ., 38, 50875104, 2004a.

Calvert, J. G. and Lindberg, S. E.: The potential influences of iodine-containing compounds on the chemistry of the troposphere in the polar spring. II. Mercury depletion, Atmos. Environ., 38, 5105-5116, 2004b.

Canosa-Mas, C. E., King, M. D., Lopez, R., Percival, C. J., Wayne, R. P., Shallcross, D. E., Pyle, J. A., and Daele, V.: Is the reaction between $\mathrm{CH}_{3}(\mathrm{O}) \mathrm{O}_{2}$ and $\mathrm{NO}_{3}$ important in the night-time troposphere?, J. Chem. Soc. Faraday Trans., 92, 2211-2222, 1996.

Christensen, J. H., Brandt, J., Frohn, L. M., and Skov, H.: Modelling of mercury in the Arctic with the Danish Eulerian Hemispheric Model, Atmos. Chem. Phys., 4, 2251-2257, 2004, http://www.atmos-chem-phys.net/4/2251/2004/.

Dastoor, A. P. and Larocque, Y.: Global circulation of atmospheric mercury: a modeling study, Atmos. Environ., 38, 147-161, 2004.

Donohoue, D. L., Bauer, D., and Hynes, A. J.: Temperature and pressure dependent rate coefficients for the reaction of $\mathrm{Hg}$ with 
$\mathrm{Cl}$ and the reaction of $\mathrm{Cl}$ with $\mathrm{Cl}$ : a pulsed laser photolysispulsed laser induced fluorescence study, J. Phys. Chem. A, 109, 7732-7741, 2005.

Donohoue, D. L., Bauer, D., Cossairt, B., and Hynes, A. J.: Temperature and pressure dependent rate coefficients for the reaction of $\mathrm{Hg}$ with $\mathrm{Br}$ and the reaction of $\mathrm{Br}$ with $\mathrm{Br}$ : a pulsed laser photolysis-pulsed laser induced fluorescence study, J. Phys. Chem. A, 110, 6623-6632, 2006.

Ebinghaus, R., Kock, H. H., Temme, C., Einax, J. W., Löwe, A. G., Richter, A., Burrows, J. P., and Schroeder, W. H.: Antarctic springtime depletion of atmospheric mercury, Environ. Sci. Technol., 36, 1238-1244, 2002.

Gårdfeldt, K. and Jonsson, M.: Is bimolecular reduction of $\mathrm{Hg}$ (II) complexes possible in aqueous systems of environmental importance, J. Phys. Chem. A, 107, 4478-4482, 2003.

Goodsite, M., Plane, J. M. C., and Skov, H.: A theoretical study of the oxidation of $\mathrm{Hg}^{0}$ to $\mathrm{HgBr}_{2}$ in the troposphere, Environ. Sci. Technol., 38, 1772-1776, 2004.

Hedgecock, I. M. and Pirrone, N.: Mercury and photochemistry in the marine boundary layer-modelling studies suggest the in situ production of reactive gas phase mercury, Atmos. Environ., 35, 3055-3062, 2001.

Hedgecock, I. M. and Pirrone, N.: Chasing quicksilver: Modeling the atmospheric lifetime of $\mathrm{Hg}_{(\mathrm{g})}^{0}$ in the marine boundary layer at various latitudes, Environ. Sci. Technol., 38, 69-76, 2004.

Hedgecock, I. M., Pirrone, N., Sprovieri, F., and Pesenti, E.: Reactive gaseous mercury in the marine boundary layer: modelling and experimental evidence of its formation in the Mediterranean region, Atmos. Environ., 37, S41-S49, 2003.

Hedgecock, I. M., Trunfio, G. A., Pirrone, N., and Sprovieri, F.: Mercury chemistry in the MBL: Mediterranean case and sensitivity studies using the AMCOTS (Atmospheric Mercury Chemistry over the Sea) model, Atmos. Environ., 39, 7217-7230, 2005.

Hedgecock, I. M., Pirrone, N., and Sprovieri, F.: Chasing quicksilver northward: mercury chemistry in the Arctic troposphere, Environ. Chem., 5, 131-134, 2008.

Hepler, L. G. and Olofsson, G.: Mercury. Thermodynamic properties, chemical equilibriums, and standard potentials, Chem. Rev., 75, 585-602, 1975.

Holmes, C. D., Jacob, D. J., and Yang, X.: Global lifetime of elemental mercury against oxidation by atomic bromine in the free troposphere, Geophys. Res. Lett., 33, L20808, doi:10.1029/ 2006GL027176, 2006.

Khalizov, A. F., Viswanathan, B., Larregaray, P., and Ariya, P. A.: A theoretical study on the reactions of $\mathrm{Hg}$ with halogens: Atmospheric implications, J. Phys. Chem. A, 107, 6360-6365, 2003.

Lin, C.-J. and Pehkonen, S. O.: Aqueous free radical chemistry of mercury in the presence of iron oxides and ambient aerosol, Atmos. Environ., 31, 4125-4137, 1997.

Lin, C.-J. and Pehkonen, S. O.: Oxidation of elemental mercury by aqueous chlorine $\left(\mathrm{HOCl} / \mathrm{OCl}^{-}\right)$: Implications for tropospheric mercury chemistry, J. Geophys. Res., 103D, $28093-$ 28 102, 1998.

Lin, C.-J., Pongprueksa, P., Lindberg, S. E., Pehkonen, S. O., Byune, D., and Jang, C.: Scientific uncertainties in atmospheric mercury models I: Model science evaluation, Atmos. Environ., 40, 2911-2928, 2006.

Lindberg, S. E., Brooks, S., Lin, C.-J., Scott, K., Meyers, T., Cham- bers, L., Landis, M., and Stevens, R.: Formation of reactive gaseous mercury in the Arctic: Evidence of oxidation of $\mathrm{Hg}^{0}$ to gas-phase $\mathrm{Hg}-\mathrm{II}$ compounds after Arctic sunrise, Water Air Soil Pollut. Focus, 1, 295-302, 2001.

Lindberg, S. E., Brooks, S., Lin, C.-J., Scott, K. J., Landis, M. S., Stevens, R. K., Goodsite, M., and Richter, A.: Dynamic oxidation of gaseous mercury in the Arctic troposphere at polar sunrise, Environ. Sci. Technol., 36, 1245-1256, 2002.

Lu, J. Y. and Schroeder, W. H.: Annual time-series of total filterable atmospheric mercury concentrations in the Arctic, Tellus, 56B, 213-222, 2004.

Lu, J. Y., Schroeder, W. H., Barrie, L. A., Steffen, A., Welch, H. E., Martin, K., Lockhart, L., Hunt, R. V., Boila, G., and Richter, A.: Magnification of atmospheric mercury deposition to polar regions in springtime: the link to tropospheric ozone depletion chemistry, Geophys. Res. Lett., 28, 3219-3222, 2001.

Munthe, J.: The aqueous oxidation of elemental mercury by ozone, Atmos. Environ., 26A, 1461-1468, 1992.

Munthe, J., Xiao, Z. F., and Lindqvist, O.: The aqueous reduction of divalent mercury by sulfite, Water Air Soil Pollut., 56, 621-630, 1991.

Pal, B. and Ariya, P. A.: Gas-phase HO-initiated reactions of elemental mercury: Kinetics, product studies, and atmospheric implications, Environ. Sci. Technol., 38, 5555-5566, 2004a.

Pal, B. and Ariya, P. A.: Studies of ozone initiated reactions of gaseous mercury: Kinetics, product studies, and atmospheric implications, Phys. Chem. Chem. Phys., 6, 572-579, 2004 b.

Pan, L. and Carmichael, G. R.: A two-phase box model to study mercury atmospheric mechanisms, Environ. Chem., 2, 205-214, 2005.

Pehkonen, S. O. and Lin, C. J.: Aqueous photochemistry of divalent mercury with organic acids, J. Air Waste Manage. Assoc., 48, 144-150, 1998.

Perovich, D. K. and Richter-Menge, J. A.: Surface characteristics of lead ice, J. Geophys. Res., 99C, 16341-16350, 1994.

Peterson, G., Munthe, J., Pleijel, K., Bloxam, R., and Kumar, A. V.: A comprehensive Eulerian modelling framework for airborne mercury species: development and testing of the tropospheric chemistry module (TCM), Atmos. Environ., 32, 829-843, 1998.

Pleijel, K. and Munthe, J.: Modelling the atmospheric mercury cycle-Chemistry in fog droplets, Atmos. Environ., 29, 1441-1457, 1995.

Poissant, L. and Pilote, M.: Time series analysis of atmospheric mercury in Kuujjuarapik/Whapmagoostui (Québec), J. Phys. IV France, 107, 1079-1082, 2003.

Rankin, A. M., Wolff, E. W., and Martin, S.: Frost flowers: Implications for tropospheric chemistry and ice core interpretation, J. Geophys. Res., 107, 4683, doi:10.1029/2002JD002492, 2002.

Raofie, F. and Ariya, P. A.: Kinetics and products study of the reaction of BrO radicals with gaseous mercury, J. Phys. IV France, 107, 1119-1121, 2003.

Raofie, F. and Ariya, P. A.: Product study of the gas-phase BrOinitiated oxidation of $\mathrm{Hg}^{0}$ : Evidence for stable $\mathrm{Hg}^{1+}$ compounds, Environ. Sci. Technol., 38, 4319-4326, 2004.

Ryaboshapko, A., Bullock, R., Ebinghaus, R., Ilyin, I., Lohman, K., Munthe, J., Petersen, G., Seigneur, C., and Wängberg, I.: Comparison of mercury chemistry models, Atmos. Environ., 36, 3881-3898, 2002.

Sander, R., Kerkweg, A., Jöckel, P., and Lelieveld, J.: Technical 
note: The new comprehensive atmospheric chemistry module MECCA, Atmos. Chem. Phys., 5, 445-450, 2005,

http://www.atmos-chem-phys.net/5/445/2005/.

Sander, R., Burrows, J., and Kaleschke, L.: Carbonate precipitation in brine - a potential trigger for tropospheric ozone depletion events, Atmos. Chem. Phys., 6, 4653-4658, 2006, http://www.atmos-chem-phys.net/6/4653/2006/.

Sandu, A. and Sander, R.: Technical note: Simulating chemical systems in Fortran90 and Matlab with the Kinetic PreProcessor KPP-2.1, Atmos. Chem. Phys., 6, 187-195, 2006,

http://www.atmos-chem-phys.net/6/187/2006/.

Schroeder, W. H. and Munthe, J.: Atmospheric mercury - An overview, Atmos. Environ., 32, 809-822, 1998.

Schroeder, W. H., Anlauf, K. G., Barrie, L. A., Lu, J. Y., Steffen, A., Schneeberger, D. R., and Berg, T.: Arctic springtime depletion of mercury, Nature, 394, 331-332, 1998.

Schwartz, S. E.: Mass-transport considerations pertinent to aqueous phase reactions of gases in liquid-water clouds, in: Chemistry of Multiphase Atmospheric Systems, NATO ASI Series, Vol. G6, edited by Jaeschke, W., pp. 415-471, Springer Verlag, Berlin, 1986.

Seigneur, C., Wrobel, J., and Constantinou, E.: A chemical kinetic mechanism for atmospheric inorganic mercury, Environ. Sci. Technol., 28, 1589-1597, 1994.

Seigneur, C., Vijayaraghavan, K., and Lohman, K.: Atmospheric mercury chemistry:sensitivity of global model simulations to chemical reactions, J. Geophys. Res., 111, D22 306, 2006.

Selin, N. E., Jacob, D., Park, R., Yantosca, R. M., Strode, S., Jaeglé, L., Holmes, C., and Jaffe, D. A.: Chemical cycling and deposition of atmospheric mercury: constraints from observations, J. Geophys. Res., 112, D02308, doi:10.1029/2006JD007450, 2007.

Shepler, B. C., Balabanov, N. B., and Peterson, K. A.: $\mathrm{Hg}+\mathrm{Br} \rightarrow \mathrm{HgBr}$ recombination and collision-induced dissociation dynamics, J. Chem. Phys., 127, 164304, doi:10.1063/1. 2777142, 2007.

Shon, Z.-H., Kim, K.-H., Kim, M.-Y., and Lee, M.: Modeling study of reactive gaseous mercury in the urban air, Atmos. Environ., 39, 749-761, 2005.

Simpson, W. R., von Glasow, R., Riedel, K., Anderson, P., Ariya, P., Bottenheim, J., Burrows, J., Carpenter, L. J., Frieß, U., Goodsite, M. E., Heard, D., Hutterli, M., Jacobi, H.-W., Kaleschke, L., Neff, B., Plane, J., Platt, U., Richter, A., Roscoe, H., Sander, R., Shepson, P., Sodeau, J., Steffen, A., Wagner, T., and Wolff, E.: Halogens and their role in polar boundary-layer ozone depletion, Atmos. Chem. Phys., 7, 4375-4418, 2007, http://www.atmos-chem-phys.net/7/4375/2007/.
Skov, H., Christensen, J. H., Goodsite, M. E., Heidam, N. Z., Jensen, B., Wåhlin, P., and Geernaert, G.: Fate of elemental mercury in the Arctic during atmospheric mercury depletion episodes and the load of atmospheric mercury to the Arctic, Environ. Sci. Technol., 38, 2373-2382, 2004.

Slemr, F., Brunke, E., Ebinghaus, R., Temme, C., Munthe, J., Wangberg, I., Schroeder, W. H., Steffen, A., and Berg, T.: Worldwide trend of atmospheric mercury since 1977, Geophys. Res. Lett., 30, 1516, doi:10.1029/2003GL016954, 2003.

Sommar, J., Gardfeldt, K., Stromberg, D., and Feng, X.: A kinetic study of the gas-phase reaction between the hydroxyl radical and atomic mercury, Atmos. Environ., 35, 3049-3054, 2001.

Steffen, A., Douglas, T., Amyot, M., Ariya, P., Aspmo, K., Berg, T., Bottenheim, J., Brooks, S., Cobbett, F., Dastoor, A., Dommergue, A., Ebinghaus, R., Ferrari, C., Gardfeldt, K., Goodsite, M. E., Lean, D., Poulain, A. J., Scherz, C., Skov, H., Sommar, J., and Temme, C.: A synthesis of atmospheric mercury depletion event chemistry in the atmosphere and snow, Atmos. Chem. Phys., 8, 1445-1482, 2008,

http://www.atmos-chem-phys.net/8/1445/2008/.

Tokos, J. J. S., Hall, B., Calhoun, J. A., and Prestbo, E. M.: Homogeneous gas-phase reaction of $\mathrm{Hg}^{0}$ with $\mathrm{H}_{2} \mathrm{O}_{2}, \mathrm{O}_{3}, \mathrm{CH}_{3} \mathrm{I}$, and $\left(\mathrm{CH}_{3}\right)_{2} \mathrm{~S}$ : Implications for atmospheric $\mathrm{Hg}$ cycling, Atmos. Environ., 32, 823-827, 1998.

Travnikov, O.: Contribution of the intercontinental atmospheric transport to mercury pollution in the Northern Hemisphere, Atmos. Environ., 39, 7541-7548, 2005.

van Loon, L., Mader, E., and Scott, S. L.: Reduction of the aqueous mercuric ion by sulfite: UV spectrum of $\mathrm{HgSO}_{3}$ and its intramolecular redox reaction, J. Phys. Chem. A, 104, 1621-1626, 2000.

van Loon, L. L., Mader, E. A., and Scott, S. L.: Sulfite stabilization and reduction of the aqueous mercuric ion: Kinetic determination of sequential formation constants, J. Phys. Chem. A, 105, 3190-3195, 2001.

Wang, Z. and Pehkonen, S. O.: Oxidation of elemental mercury by aqueous bromine: atmospheric implications, Atmos. Environ., 38, 3675-3688, 2004.

Xiao, Z. F., Munthe, J., Stromberg, D., and Lindqvist, O.: Photochemical behavior of inorganic mercury compounds in aqueous solution, in: Mercury as a Global Pollutant - Integration and Synthesis, edited by Watras, C. J. and Huckabee, J. W., pp. 581592, Lewis Publishers, 1994. 